

\title{
Conventional and emergent technologies for honey processing: A perspective on microbiological safety, bioactivity, and quality
}

\author{
Hana Scepankova $^{1}$ (ㅇ | Carlos A. Pinto ${ }^{1}$ (ㅇ) | Vanessa Paula $^{2}$ () |

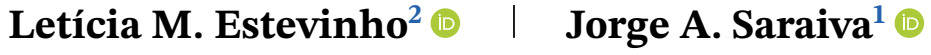

${ }^{1}$ LAQV-REQUIMTE, Chemistry

Department, University of Aveiro, Aveiro, Portugal

${ }^{2}$ Centro de Investigação de Montanha, Instituto Politécnico de Bragança, Bragança, Portugal

\section{Correspondence}

Letícia M. Estevinho, Centro de Investigação de Montanha, Instituto Politécnico de Bragança, 5300-252 Bragança, Portugal. Email: leticia@ipb.pt

Jorge A. Saraiva, LAQV-REQUIMTE, Chemistry Department, University of Aveiro, Campus Universitário de Santiago, 3810-193 Aveiro, Portugal.

Email:jorgesaraiva@ua.pt

\begin{abstract}
Honey is a natural food of worldwide economic importance. Over the last decades, its potential for food, medical, cosmetical, and biotechnological applications has been widely explored. One of the major safety issues regarding such applications is its susceptibility to being contaminated with bacterial and fungi spores, including pathogenic ones, which may impose a hurdle to its consumption in a raw state. Another factor that makes this product particularly challenging relies on its high sugar content, which will lead to the formation of hydroxymethylfurfural (HMF) when heated (due to Maillard reactions). Moreover, honey's bioactivity is known to be affected when it goes through thermal processing due to its unstable and thermolabile components. Therefore, proper food processing methodologies are of utmost importance not only to ensure honey safety but also to provide a high-quality product with low content of HMF and preserved biological properties. As so, emerging food processing technologies have been employed to improve the safety and quality of raw honey, allowing, for example, to reduce/avoid the exposure time to high processing temperatures, with consequent impact on the formation of HMF. This review aims to gather the literature available regarding the use of conventional and emergent food processing technologies (both thermal and nonthermal food processing technologies) for honey decontamination, preservation/enhancement of honey biological activity, as well as the sensorial attributes.

\section{KEYWORDS}

antibacterial activity, antioxidant activity, emergent technologies, honey, nonthermal processing, physicochemical quality, thermal processing
\end{abstract}

Nomenclature: ABTS, 2,2'-azinobis-(3-ethylbenzothiazoline-6-sulfonic acid) (free radical scavenging activity); DA, diastase activity; DN, diastase number; DPPH, 2,2-diphenyl-1-picrylhydrazyl (free radical scavenging activity); FRAP, ferric reducing antioxidant power (antioxidant capacity); HMF, hydroxymethylfurfural; HPP, high pressure processing; MGO, methylglyoxal; ORAC, oxygen radical absorbance capacity; TPC, total phenolic content; UV light, ultraviolet light 


\section{1 | INTRODUCTION}

Honey has been used as food and natural remedy since ancient times (Eteraf-oskouei \& Najafi, 2013). Currently, honey consumption is continuously growing, mainly due to the increase in the world population and the growing demand for natural and healthy products (García, 2018). Likewise, honey is used in the pharmaceutical and cosmetic industries, mainly due to its effectiveness in wound healing and burns (McLoone et al., 2020).

Due to its natural antioxidants and their synergic interaction with other components, honey has the potential capacity to serve as an important source of antioxidants in human nutrition and can exhibit beneficial effects on human health, as antitumor and cardiovascular protection (Erejuwa et al., 2014; Olas, 2020). The antibacterial activity of honey is one of the most important findings that was first recognized in 1892 by the Dutch scientist Van Ketel (Scepankova et al., 2017). Recent research indicates that the effectiveness of honey in many of its medical uses is due to its antibacterial activity that can inhibit Gram-positive and Gram-negative bacteria, including multidrug-resistant strains Staphylococcus aureus (MRSA) (Combarros-Fuertes et al., 2020), and some species of fungi (Almasaudi, 2021; Fernandes et al., 2021; Manyi-loh et al., 2010; Nolan et al., 2019; Roberts et al., 2019) and viruses (Abedi et al., 2021; Hossain et al., 2020; Semprini et al., 2019; Watanabe et al., 2014).

Thermal processing is an important step in honey production, which directly affects its essential composition and quality. Honey is subjected to thermal processing to delay crystallization, to remove the contaminating microorganisms, to reduce viscosity, and to prevent crystallization and fermentation (Singh \& Singh, 2018). The major concern arising from thermal processing comes from the formation of compounds that are not naturally present in foods but may develop during heating. Such compounds may possess harmful effects such as mutagenic, carcinogenic, and cytotoxic effects, due to the presence of neoformed contaminants. Hydroxymethylfurfural (HMF) is formed upon thermal processing and/or long-term storage as an intermediate product of Maillard reaction (Shapla et al., 2018) and is a well-known neo-formed contaminant and its safe level of daily consumption is not well clarified (Husøy et al., 2008). However, some studies reported tolerable daily intake of HMF in doses ranging from 80 to $100 \mathrm{mg} / \mathrm{kg}$ body weight (Shapla et al., 2018). It is important to notice that HMF in honey is extensively studied as an indicator of honey quality and freshness. Indeed, overheated honey (as a result of uncontrolled and excessive thermal processing) can contain very high HMF levels (Biluca et al., 2014). Özkök and Silici (2016) concluded that high HMF content of honey may affect the human health adversely and thus HMF level must be controlled. Therefore, International Honey Commission (IHC) established the content of HMF as well as diastase activity (DA) as the international standards of quality used to control the honey freshness and limit for thermal processing of honey (Bogdanov, 2009). Likewise, thermal processing can result in severe physical and chemical degradation of honey, with a significant impact on color, flavor and antioxidant and antibacterial properties (Chaikham et al., 2016; Chua et al., 2014; Zarei et al., 2019). Nevertheless, honey must be delivered to the consumers with its essential composition and minimally altered quality (Doménech et al., 2010).

Considering that honey is a raw food product, it may contain pathogenic microorganisms, such as bacterial spores (Clostridium botulinum strains), which, despite having a small effect on honey degradation, constitute severe concerns regarding its safe consumption, especially by immunosuppressed people or by children and pregnant woman. Honey is the only dietary vehicle so far definitively linked to infant botulism (European Commission, 2002). As recommended by the World Health Organization (WHO), for the prevention of infant botulism, it is essential not to use honey as a sweeter in preparations for infants $<12$ months of age (World Health Organization, 2018). Although conventional thermal processing is effective in reducing viscosity and microbial decontamination, the lack of this technique lays in the inefficiency to inactivate bacterial spores such as the C. botulinum.

Currently, there is increased consumers' demand for minimally processed foods with improved nutritional and sensorial characteristics. Emergent technologies for food processing, especially nonthermal technologies, are increasingly replacing the conventional thermal pasteurization techniques (Jan et al., 2017). Emergent processing technologies may constitute a promising alternative to ensure honey microbiological safety with preserved freshlike quality (Lee et al., 2019).

Therefore, the present paper aims to review the effect of conventional thermal processing and emergent food processing technologies (both thermal and nonthermal) on honey quality, microorganisms, and bioactive properties.

\section{2 | EFFECT OF CONVENTIONAL THERMAL PROCESSING ON HONEY'S QUALITY}

Thermal processing of food is still considered the simplest and most effective method for preventing foods from microbial spoilage. In the honey industry, thermal processing is widely applied for the pasteurization. Even though bacteria cannot reproduce in honey (due to low moisture, $\mathrm{pH}$, water activity, and high acidity as well as other 
antibacterial components), they can be transmitted when honey is used as an ingredient in the preparation of other foods and multiply until they deteriorate the product (Serreira et al., 2010). For instance, Iurlina and Fritz (2005) found high levels of aerobic mesophilic bacteria in commercial honey (1200 CFU/g), artisanal honey (1100 $\mathrm{CFU} / \mathrm{g}$ ), and bulk honey (500 CFU/g) from Argentina. Those samples exceeded the maximum limit established by the Southern Common Market (MERCOSUR) regulations (100 CFU/g) (Finola et al., 2007).

Despite this, the osmophilic yeasts (mainly Saccharomyces) are found to be the dominant yeasts fermenting honey, able to withstand the concentrated sugars and limited level of water (Belitz et al., 2009). Their presence in honey is unavoidable because bees collect them together with the nectar, pollen, and honeydew. Also, inappropriate honey handling and cross-contamination with equipment or other products also contribute to the microbial contamination of honey. Honeys with a high initial yeast count and borderline moisture content (between 17.1 and 20\%) may start to ferment after crystalizing (Snowdon \& Cliver, 1996). The spontaneous crystallization attributes to phase separation, which increases the water concentration in the liquid phase and the water activity up to the normal levels (above 0.61), which is suitable for yeasts multiplication, thus promoting honeys' fermentation (Ma et al., 2017; Zamora \& Chirife, 2006). Commonly, the fermentation of honey occurs on the top of the barrel or jar, where the water content is increased and such honey is not likely to be palatable or marketable (Snowdon \& Cliver, 1996). Unlike milk or other dairy products, pasteurization of honey is done not only to eliminate the spoilage microorganisms but also to remove any chance of fermentation, as it brings down the moisture content to a safe limit and delays crystallization (Singh \& Singh, 2018).

There are various thermal processes for maintaining the liquid consistency of honey for a longer time, increasing shelf life. The high-temperature, short-time heating is a basic method of pasteurization widely used in industry, for flash pasteurization. The flash pasteurization of honey at $80^{\circ} \mathrm{C}$ for only $30 \mathrm{~s}$, followed by rapidly cooling, has been reported to eliminate all fungi and yeasts (Tosi et al., 2004). In addition, the process melts glucose microcrystals and removes air bubbles, delaying postprocessing crystallization-as required by large honey retailers. Although milk can be pasteurized by high-temperature, short-time heating at a temperature of $72^{\circ} \mathrm{C}$ for only $15 \mathrm{~s}$ (Lucey, 2015), this procedure did not reduce yeast counts in honey (Schvezov et al., 2020). On the other hand, Gonnet et al. (1964) suggested $78^{\circ} \mathrm{C}$ and a longer time (6-7 $\mathrm{min}$ ) is the best pasteurizing condition. It is important to consider, however, that spores are resistant to pasteurization, but sterilization could cause severe changes in the honey qual- ity. According to Codex Alimentarius (2001), honey should not be submitted to an extreme heating temperature, as it would impact honey's essential composition and/or lower its quality. To date, no guideline is available regarding the use of temperature and time for pasteurization of a particular type of honey (Chua et al., 2014).

The quality of honey is vital for national and international markets to ensure competitive prices and human health. HMF and DA are important parameters used for evaluating honey quality and freshness. These parameters express the ability to maintain original chemical-physical and sensorial features of honey over time (Baglio, 2018). Indeed, when the DA (expressed as diastase number [DN]) drops below the acceptable limit of $8 \mathrm{DN}$ (except for honey with a low natural enzyme content, not less than $3 \mathrm{DN}$ ) and/or HMF exceeds $40 \mathrm{mg} / \mathrm{kg}$ (except for honey from tropical zones, where the cutoff is $80 \mathrm{mg} / \mathrm{kg}$ ), the quality of honey is considered degraded, and the product should be designated as baker's honey (Thrasyvoulou et al., 2018). Codex Alimentarius and European Directive require that HMF and DA contents should be determined after honey processing and blending (Thrasyvoulou et al., 2018). Table 1 summarizes HMF content and DA changes in honey after thermal processing. Chaikham et al. (2016) reported that the conventional thermal processing at $90^{\circ} \mathrm{C}$ for $5 \mathrm{~min}$ sufficiently reduced the total plate counts and yeast molds in all honeys and kept the HMF within the standard limit $(40 \mathrm{mg} / \mathrm{kg})$. However, in this study, the DA was lower than $8 \mathrm{DN}$, indicating excessive thermal processing. Kowalski et al. (2012) reported no DA in honeydew honey after increasing the heating time above $30 \mathrm{~min}$ at $90^{\circ} \mathrm{C}$. In the same line, several studies pointed out that prolonged heating at high temperatures causes a high concentration of HMF in honey. For instance, the honey processed at the $75^{\circ} \mathrm{C}$ for $24 \mathrm{~h}$ presented too high values of the HMF (from 173.4 to $226.35 \mathrm{mg} / \mathrm{kg}$ ) (Karabournioti \& Zervalaki, 2001). In comparison, Brazilian Apis mellifera honey processed at the same conditions $\left(75^{\circ} \mathrm{C}\right.$ for $\left.24 \mathrm{~h}\right)$ had an even higher HMF concentration $(695.40 \mathrm{mg} / \mathrm{kg}$ ) (Biluca et al., 2014). On the other hand, when honey is submitted to higher temperatures but during reduced periods of time, the HMF levels tend to be much lower, being within the stablished limits. This has been shown by several authors including Czipa et al. (2019), when honey was heated at $80^{\circ} \mathrm{C}$ for $60 \mathrm{~min}$, and Akhmazillah and Farid (2015), for 10 min of processing at $70^{\circ} \mathrm{C}$.

Therefore, the basic concept of honey pasteurization is to heat the honey only to the lowest temperature and for the shortest period of time (Escriche et al., 2009; Tosi et al., 2004). Currently, industrial heating, up to $55^{\circ} \mathrm{C}$, is the most accepted process for the prevention of honey crystallization and de-crystallization (liquefaction) (Bucekova, Juricova, Di Marco, et al., 2018). The International Honey 


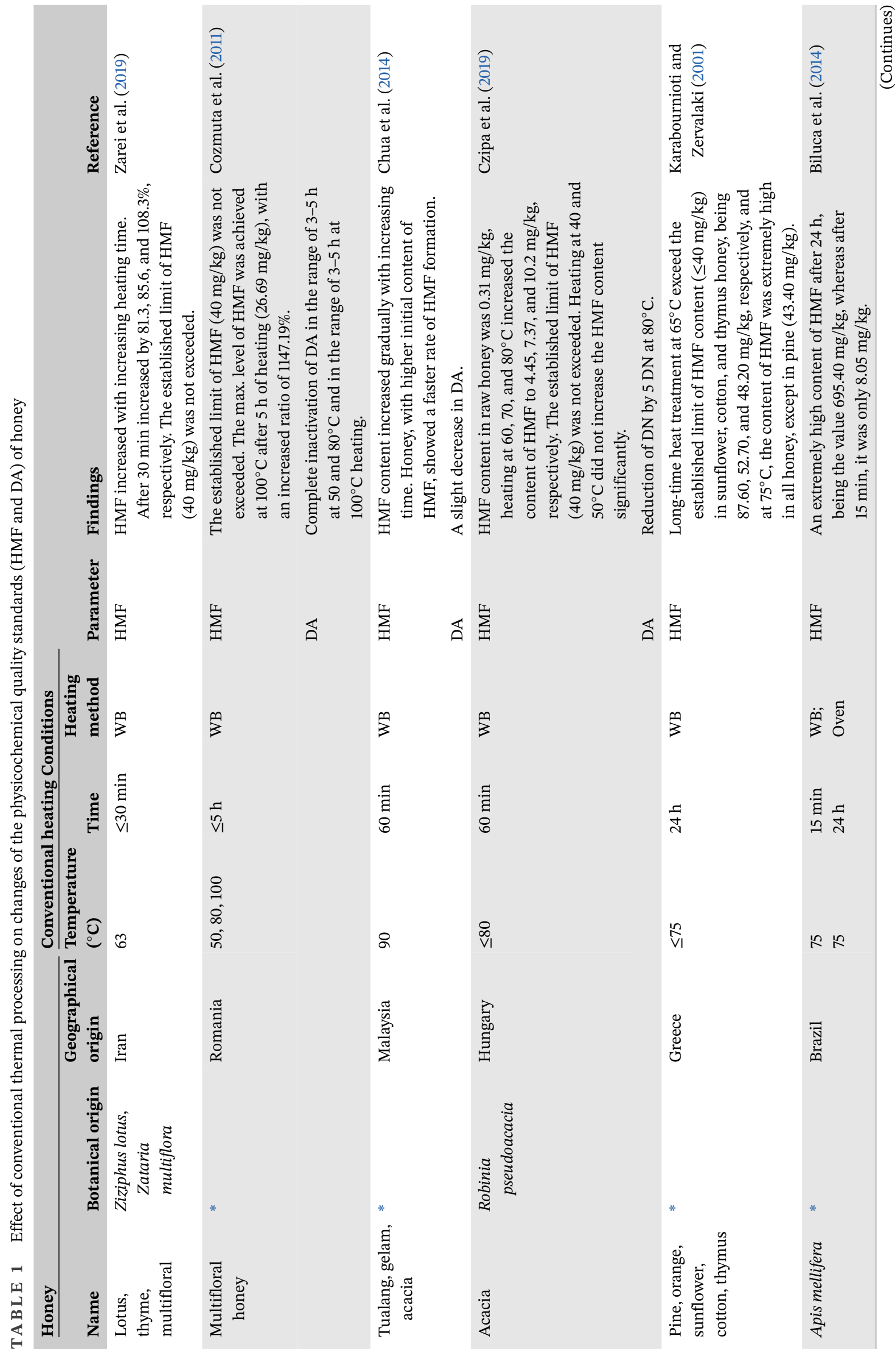




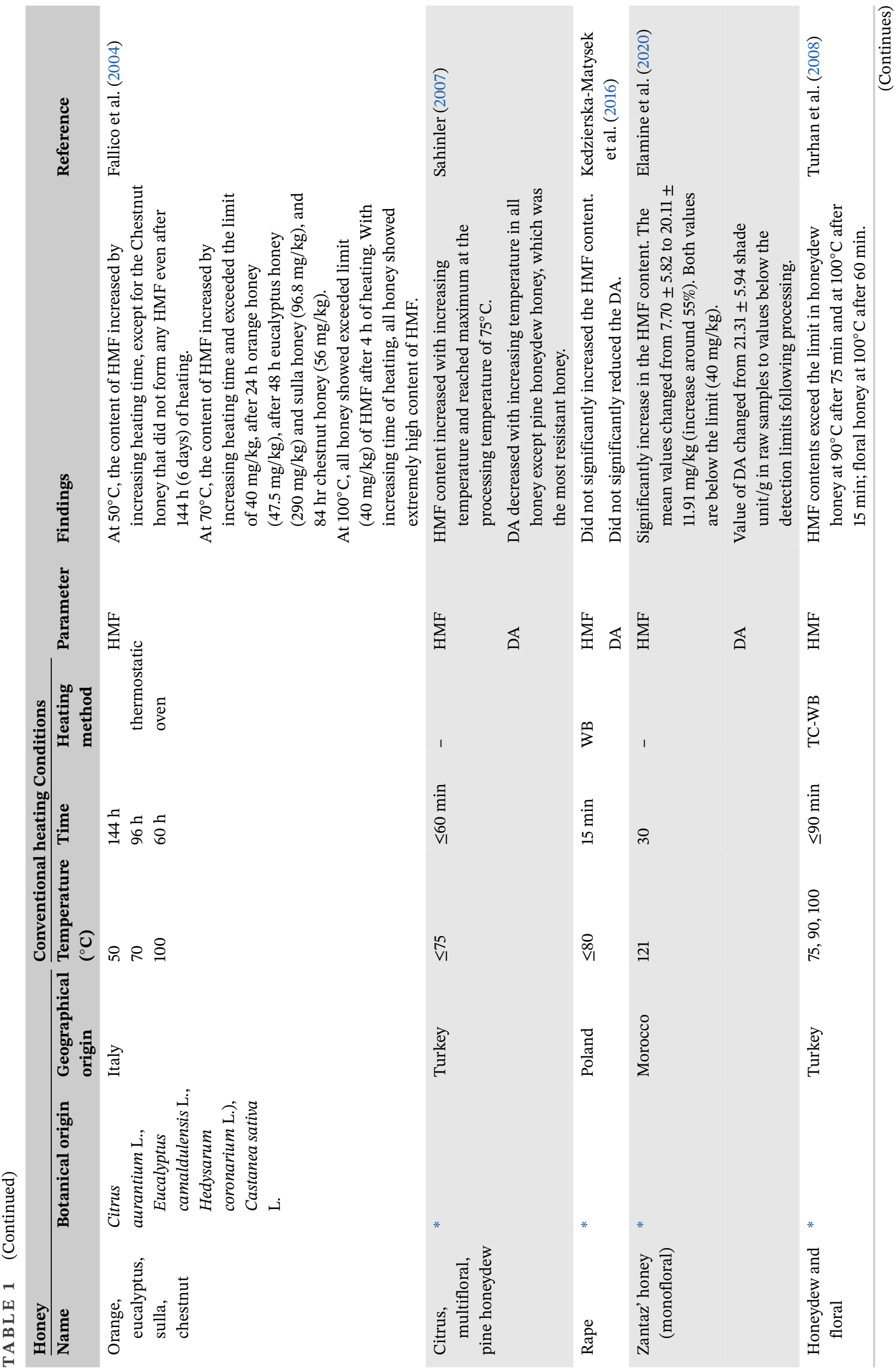




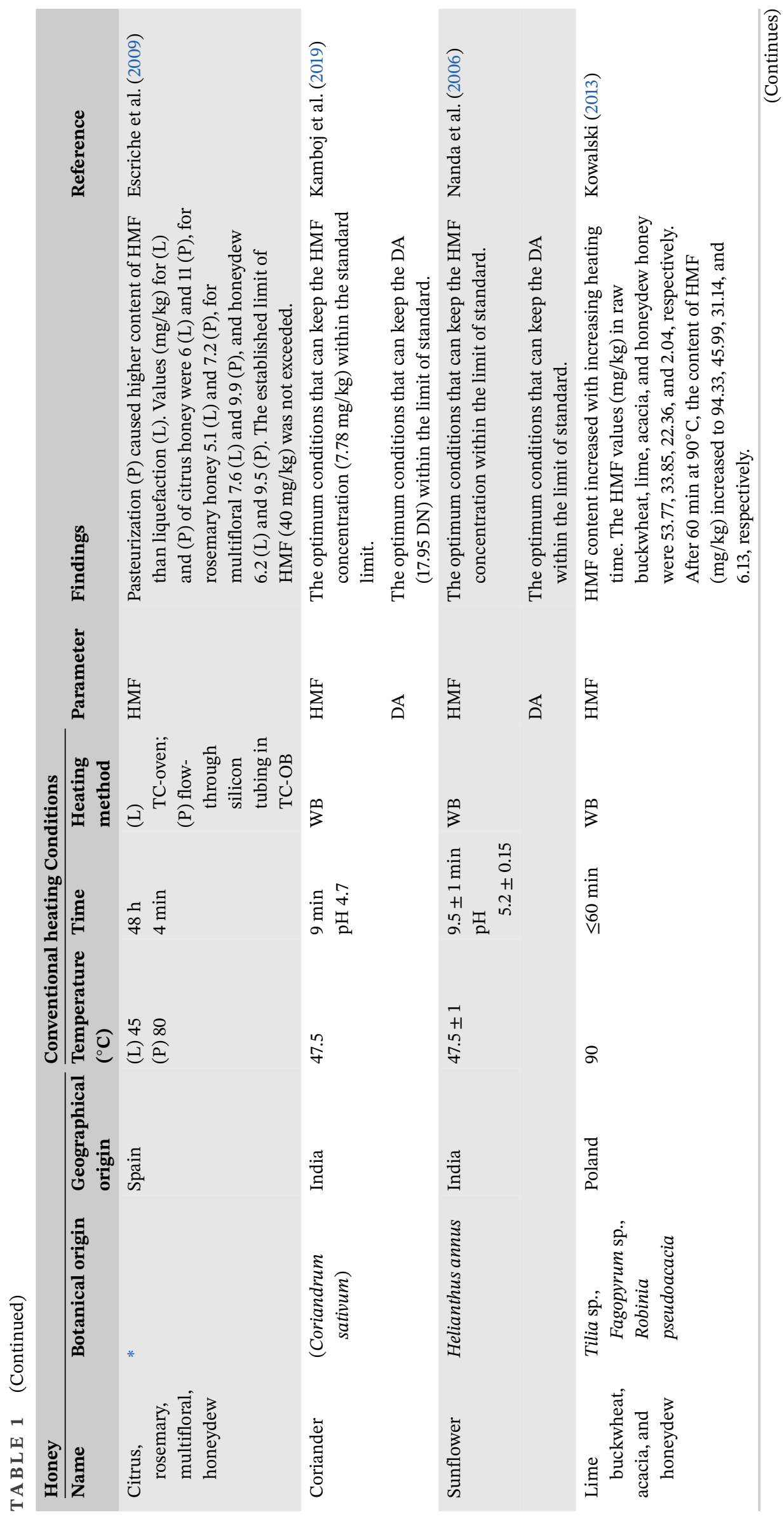




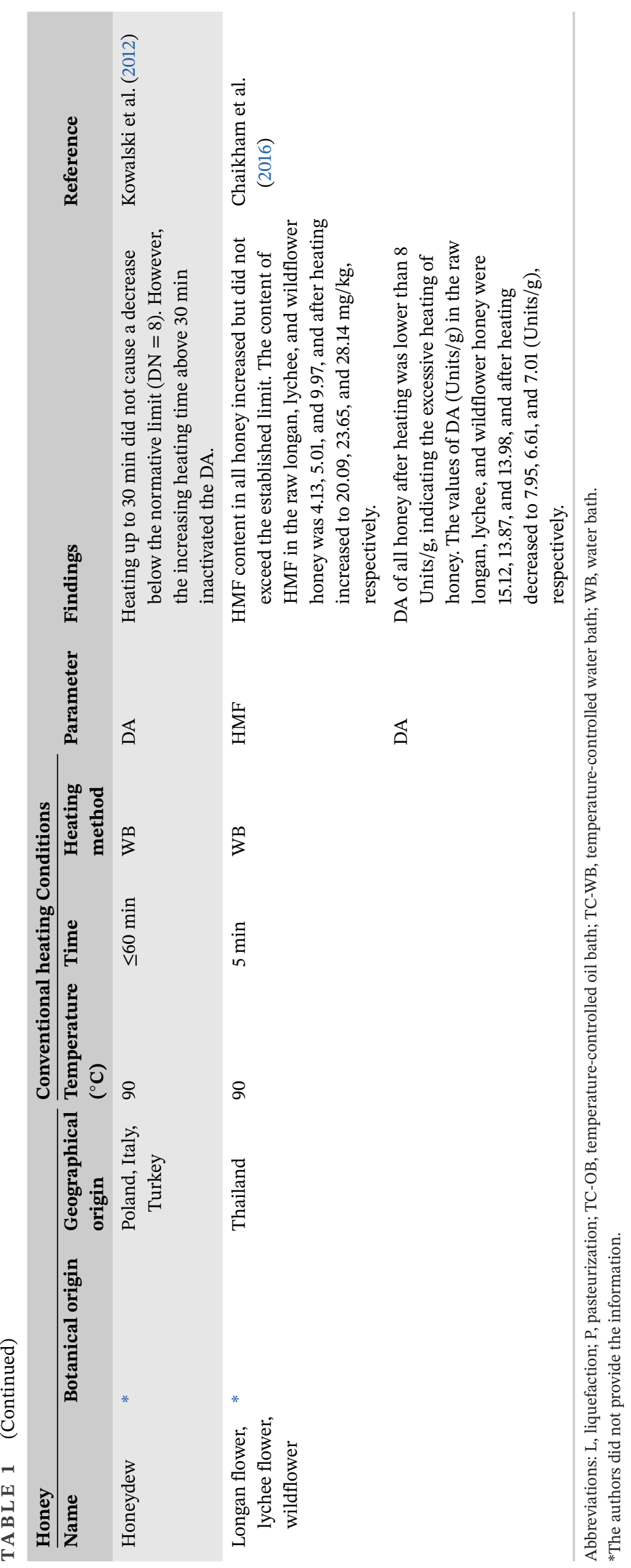


Commission recommends that the crystallized honey may be liquefied by heating at no more than $40^{\circ} \mathrm{C}$ (International Honey Commission, 2002). According to of Organic Federation of Canada, heating of honey for extraction shall not exceed $35^{\circ} \mathrm{C}$ and the de-crystallization temperature shall not exceed $47^{\circ} \mathrm{C}$; in case the product is heated above such temperatures, it should only be used as an ingredient in a multi-ingredient product (Organic Federation of Canada, 2020). Despite this, the duration of liquefaction at mild temperature is not uniform and the honeys are often heated until complete dissolution of crystals. Moreover, it starts to liquefy at the sides of the container, leading to overheating of honey in some zones (Kretavičius et al., 2010). In order to prevent this situation, honey should be homogenized during in-package heating or processed in continuous followed by hygienic packaging.

The origin of honey has also been referred to be an important factor affecting the formation of HMF, particularly when honey is processed at low temperatures (Fallico et al., 2004). The study carried out by Bucekova, Juricova, Di Marco, et al. (2018) showed that samples of wildflower honey (50-72\% Brassicaceae pollen) completely de-crystallized within $14 \mathrm{~h}$ of heating at $45^{\circ} \mathrm{C}$, whereas rapeseed honey (80-91\% Brassicaceae pollen) did not liquefy even within $120 \mathrm{~h}$. Cozmuta et al. (2011) demonstrated that after $5 \mathrm{~h}$ of heating multifloral honey at the temperature of $50^{\circ} \mathrm{C}$, the formation of HMF increased by $192.05 \%$, and the DA was completely inactivated. Therefore, the same duration of the liquefaction process at constant temperatures may decrease the quality in some honeys while preserving the characteristics of others; further studies are needed to clarify this question. The changes in the concentration of HMF and the DA during thermal processing (pasteurization and liquefaction) are also related to other factors including $\mathrm{pH}$, free acidity content, lactone content, and mineral content, which, in turn, are related to the botanical origin of the honey (Shapla et al., 2018).

Some authors advocate that the concentration of HMF is a thermal index rather than a quality standard, and that other variables should be introduced in the evaluation of honey quality (Bucekova et al., 2020; Fallico et al., 2004).

\section{1 | Changes in the biological activity of honey after conventional thermal processing}

During thermal processing, changes occurring in physicochemical quality indicators of honey (i.e., HMF and DA) are merely significant from compliance with national and international legal norms. However, from the nutritional point of view, the decrease of the biological activity during the thermal processing of honey is of particular importance because it may affect honey's nutritional quality and health benefits (Zarei et al., 2019). This section discusses thermal processing's effect on changes in honey's antioxidant properties (Table 2) and antibacterial activity.

\subsection{1 | Changes in antioxidant properties of honey}

Phenolic compounds of honey behave as antioxidants in a variety of ways, including the direct trapping of reactive oxygen species (ROS), inhibition of enzymes responsible for producing superoxide anions, chelation of transition metals involved in the process of forming radicals, and prevention of the peroxidation process by reducing alkoxyl and peroxyl radicals (Pyrzynska \& Biesaga, 2009). Several studies observed a correlation between total phenolic content (TPC) and antioxidant activity, suggesting that phenolic compounds are the main compounds responsible for that bioactive property. However, due to the complex composition of honey, the interaction among the different nonphenolic compounds and the possible synergism between them may also play an important role (KędzierskaMatysek et al., 2021). Among those compounds are proteins, amino acids, peptide inhibitors of oxidative enzymes, enzymes such as catalase or glucose oxidase, vitamins such as ascorbic acid and $\alpha$-tocopherol, and organic acids, which may chelate metals and favor polyphenols' action. In addition, owing to the complex nature of the matrix and the involvement of multiple reaction characteristics and mechanisms, different antioxidant assays provide different results. Each assay assesses diverse mechanisms, in which a wide variety of phytochemicals take part (Combarros-Fuertes et al., 2019; Scepankova et al., 2017). Therefore, the determination of the antioxidant activity of honey is generally performed by using a combination of different in vitro antioxidant activity assays (2,2-diphenyl1-picrylhydrazyl [free radical scavenging activity] [DPPH], ferric reducing antioxidant power [antioxidant capacity] [FRAP], 2,2'-azinobis-(3-ethylbenzothiazoline-6-sulfonic acid) [free radical scavenging activity] [ABTS], and oxygen radical absorbance capacity [ORAC]) together with the quantification of TPC, total flavonoid compounds, and individual phenolic compounds (Karabagias et al., 2018).

During thermal processing, the antioxidant activity of different types of honey is changed. Zarei et al. (2019) recently investigated the effect of thermal processing at $63^{\circ} \mathrm{C}$ for $30 \mathrm{~min}$ on the lotus, thyme, and multifloral honey from Iran. They found a significant reduction of TPC in all honey, being the values for the unprocessed and processed lotus honey 609 and $482 \mathrm{mg} / \mathrm{kg}$, for thyme 538 and $447 \mathrm{mg} / \mathrm{kg}$, and multifloral honey 462 and $404 \mathrm{mg} / \mathrm{kg}$, respectively. Thyme honey showed a decrease in DPPH 


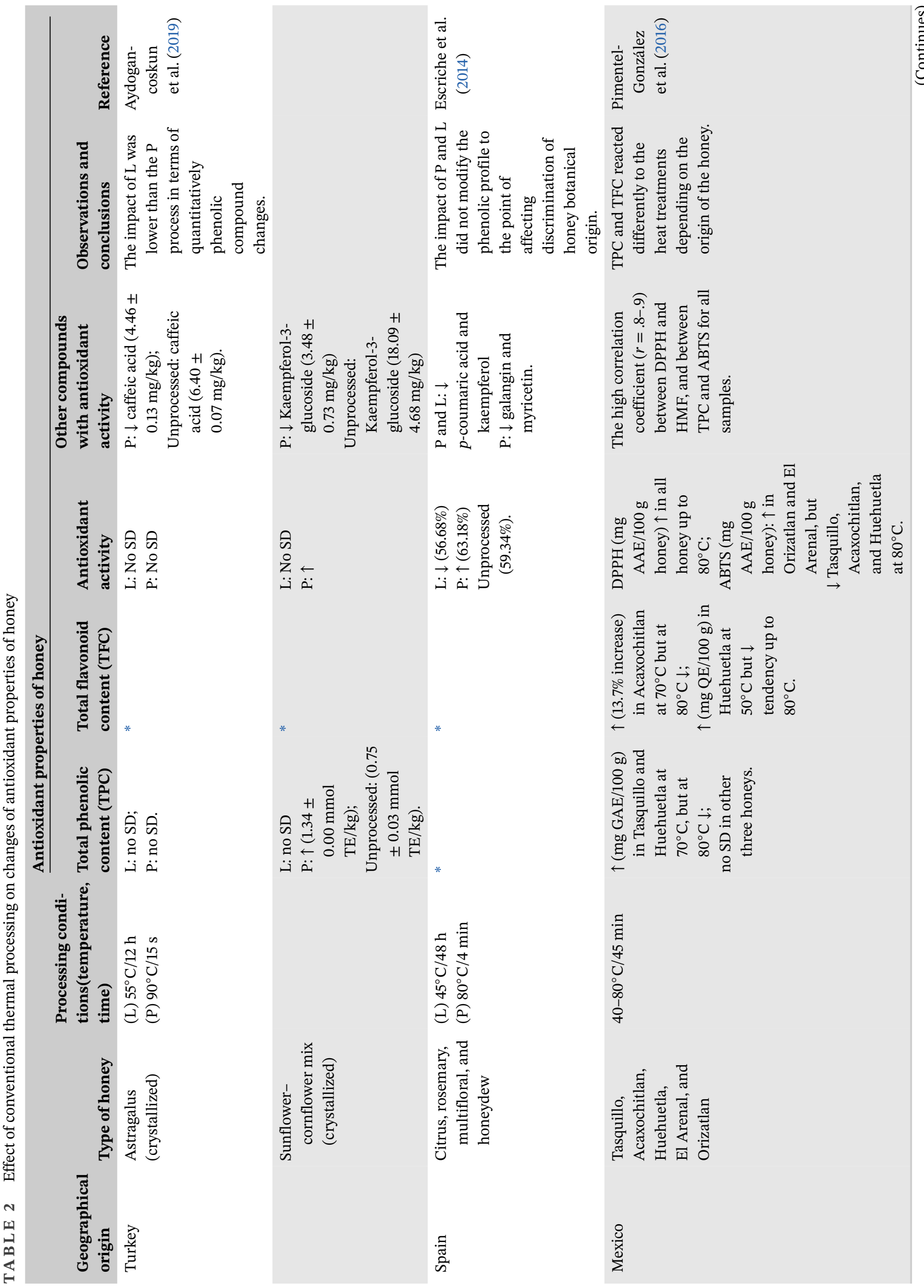




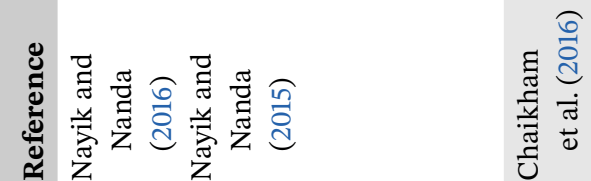

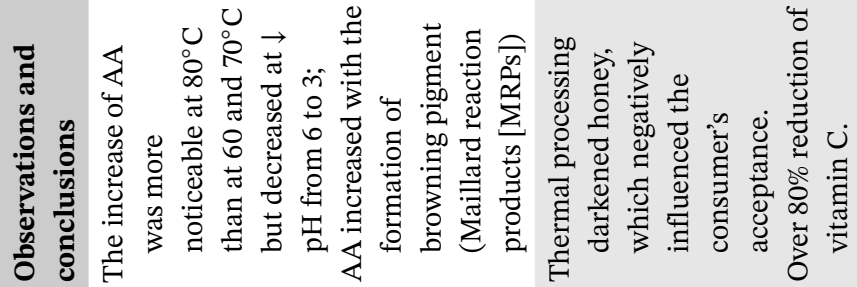
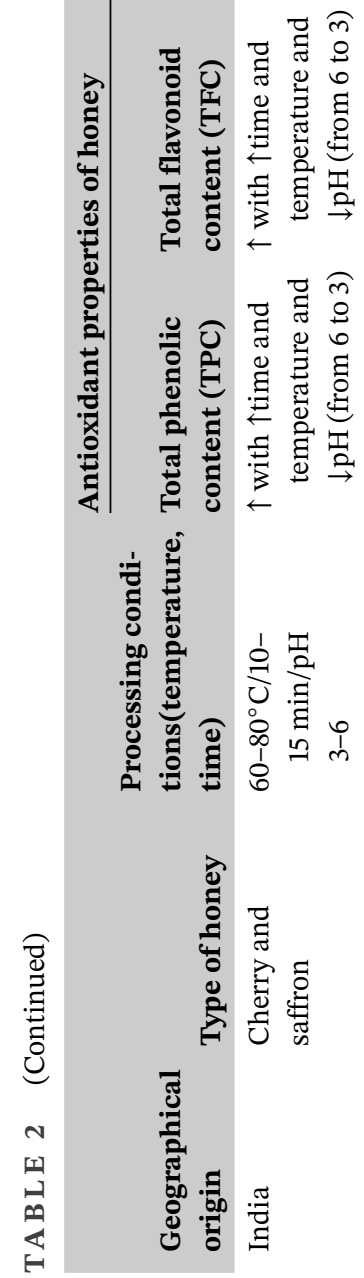

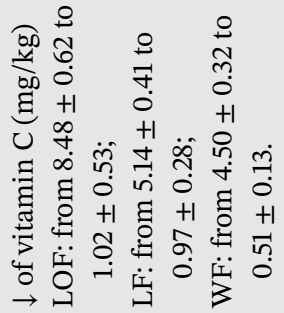

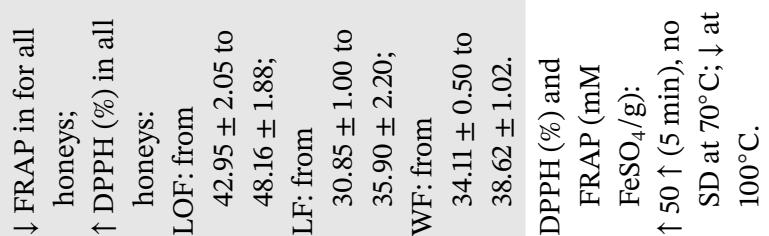
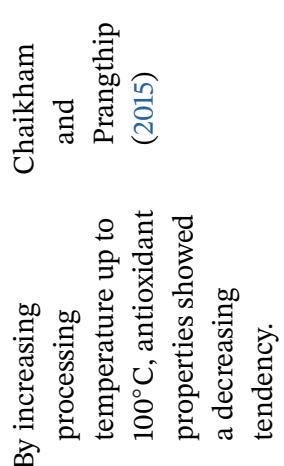

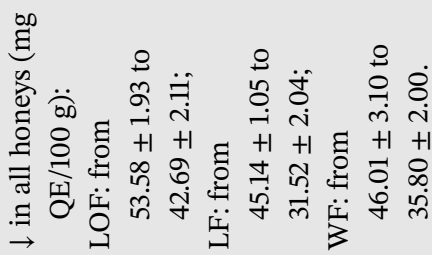

का हี

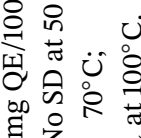

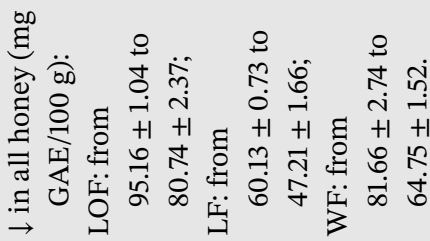

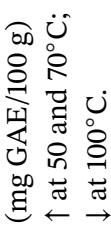
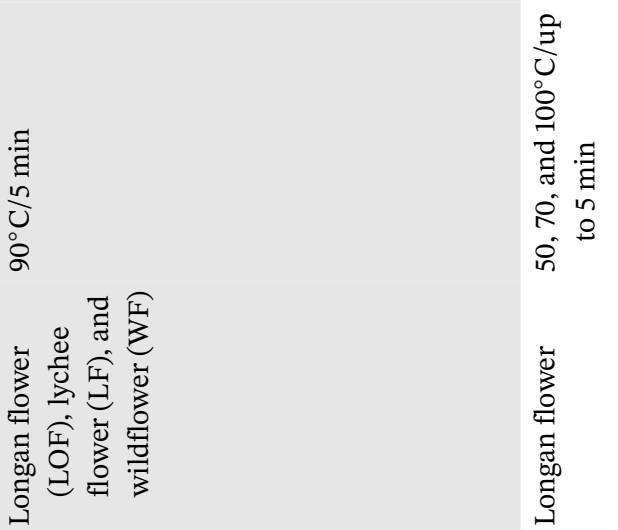

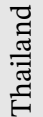




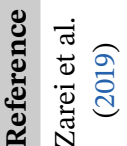
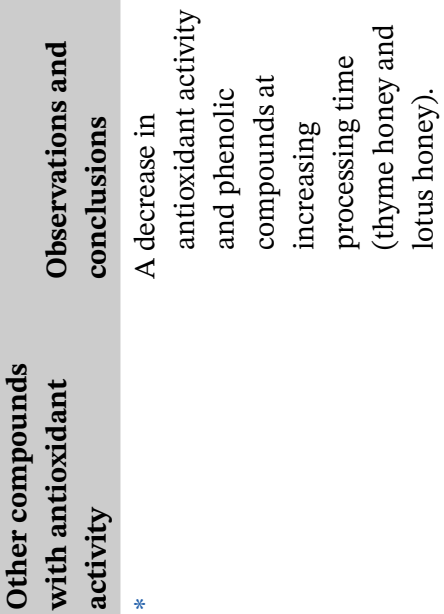

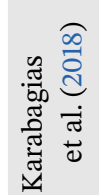

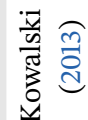

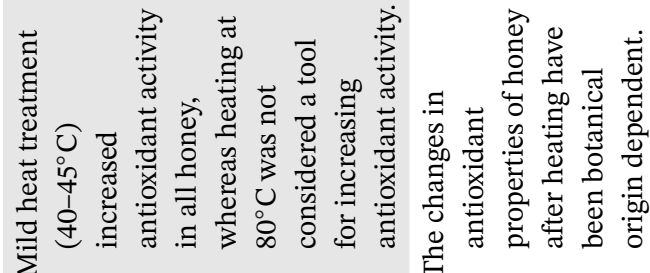

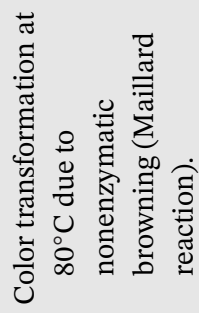

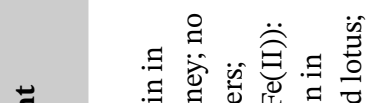

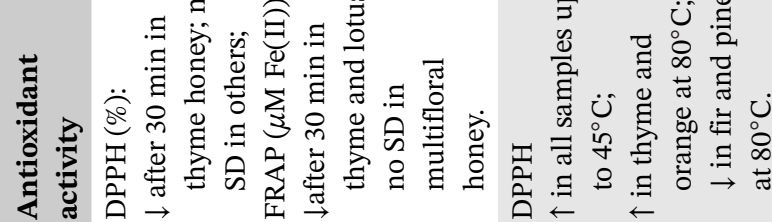
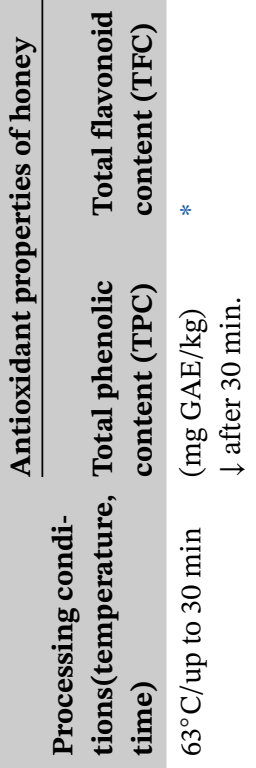

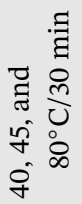

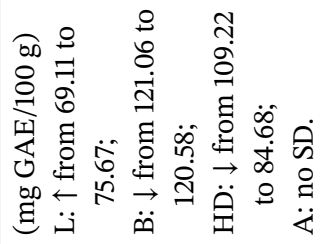

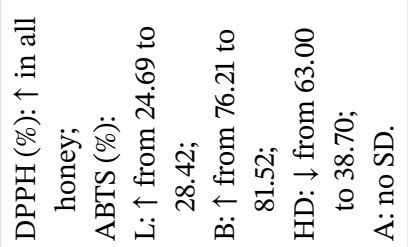
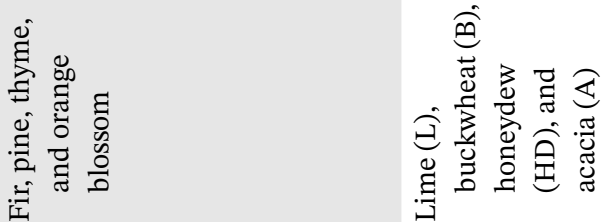

닌

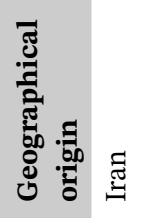

Uूँ

즐 


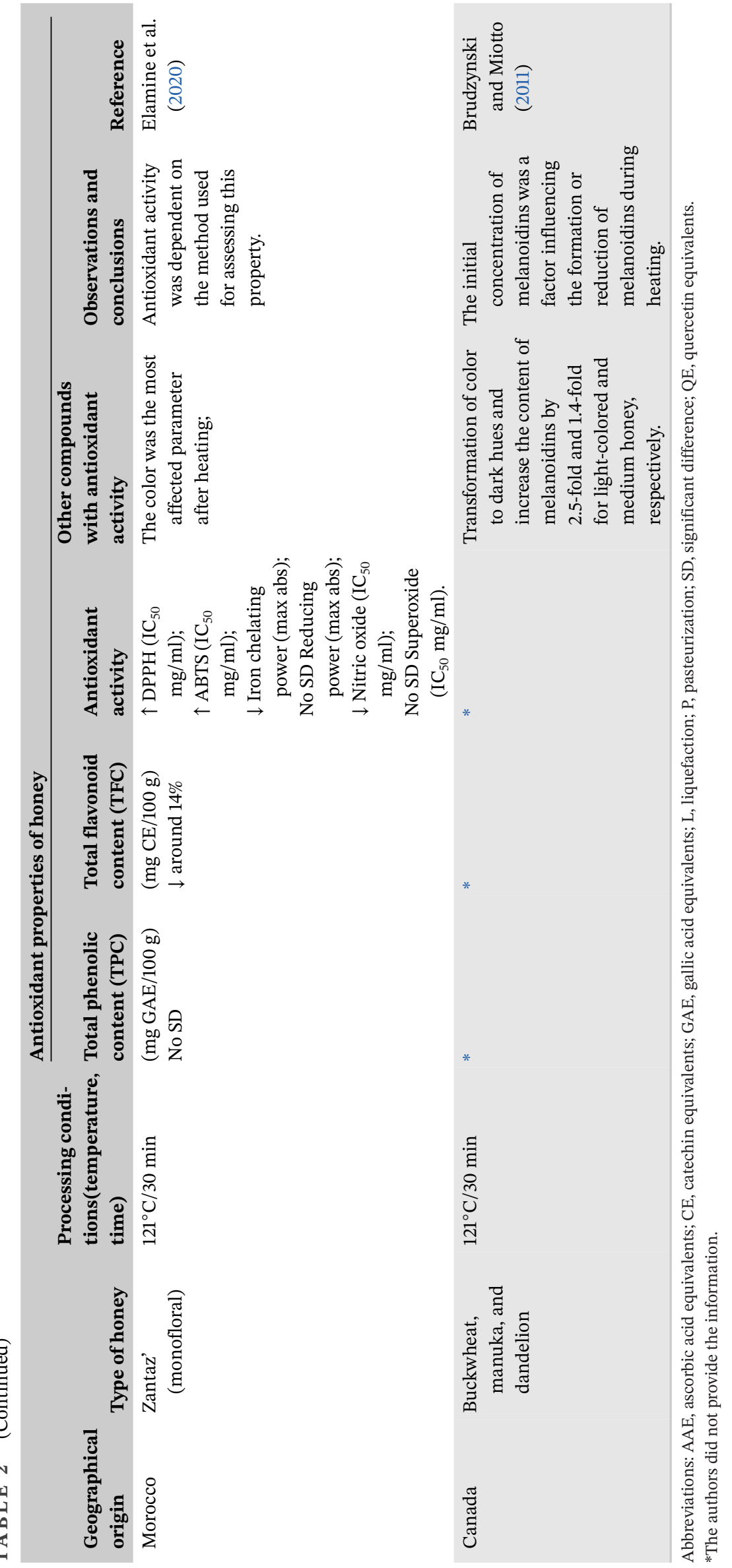


radical scavenging activity, and the FRAP values decreased in both thyme and lotus honey, whereas no changes in multifloral honey were observed. Thyme honey, even as it is light-colored honey, is the honey with a great antioxidant capacity due to its characteristically high content of vitamin C (up to $170 \mathrm{mg} / 100 \mathrm{~g}$ ) (Leon-Ruiz et al., 2011) than in other botanical honey (average content is $25 \mathrm{mg} / \mathrm{kg}$ ) (Majkut et al., 2021). However, thermal processing negatively affects the vitamin $\mathrm{C}$ content in honey. Chua et al. (2014) found about 11-14\% decline of vitamin C in tualang, gelam, and acacia honey, whereas Chaikham et al. (2016) reported an even higher decline of $80 \%$ in longa, lychee, and wildflower honey after thermal processing. The decrease in honey's antioxidant activity in some honeys may be related to reducing vitamin $\mathrm{C}$ content caused by thermal processing. Majkut et al. (2021) observed that short-time exposure $\left(100^{\circ} \mathrm{C} / 15 \mathrm{~min}\right)$ reduced vitamin $\mathrm{C}$ content $(\leq 50 \%)$ but increased TPC $(\geq 27 \%)$ and antioxidant activity (FRAP; $\geq 106 \%$ ) of honey.

Several studies pointed out that the changes in antioxidant properties of honey after thermal processing are botanical origins dependent. For instance, the thermal processing at $80^{\circ} \mathrm{C}$ for $30 \mathrm{~min}$ decreased the antioxidant activity (ABTS) of honey with the highest initial pigment content (fir and pine honey). In contrast, it increased the antioxidant activity in honey with lower initial pigment content (thyme and orange honey) (Karabagias et al., 2018). According to Elamine et al. (2020), heating lightcolored honey, honey with lower amounts of polyphenols, or lower antioxidant activity induces more accentuated changes than those observed in darker honey or those already possessing higher amounts of polyphenols or higher antioxidant activity. For instance, Kowalski (2013) demonstrated that TPC and antioxidant activity in lightcolored lime honey increased after thermal processing $\left(90^{\circ} \mathrm{C}\right.$ for $\left.60 \mathrm{~min}\right)$, whereas in dark, phenolic compoundsrich honeydew honey the opposite effect was observed. Also, the change in the antioxidant activity of honey depends on the $\mathrm{pH}$ of honey. Generally, different kinds of honey have different $\mathrm{pH}$, depending primarily on the honey's floral origin. Nayik and Nanda (2015) found that increasing processing temperature (from 60 to $80^{\circ} \mathrm{C}$ ) and decreasing $\mathrm{pH}$ of honey from 6 to 3 (increase in acidity) increased the antioxidant activity of saffron honey comparable results were found for cherry honey (Nayik \& Nanda, 2016). Pasteurization at $90^{\circ} \mathrm{C}$ for $5 \mathrm{~min}$ is effective in all floral honeys (while keeping the HMF within the standard limit of $40 \mathrm{mg} / \mathrm{kg}$ ); however, the antioxidant activity can increase or decrease, depending on the type of honey (Saric et al., 2013). Some authors observed a selective increase of individual phenolic compounds during the short-time pasteurization conditions. For instance, Aydogan-coskun et al. (2019) demonstrated that indus- trial pasteurization at $90^{\circ} \mathrm{C}$ for only $15 \mathrm{~s}$ almost doubled the concentration of kaempferol in sunflower-cornflower honey. These authors observed that the pasteurization process increased the amount of kaempferol-3-glucoside and increased the TPC and antioxidant activity. On the other hand, Chaikham and Prangthip (2015) observed decreased antioxidant properties (TPC, DPPH, and FRAP) in longan flower honey after short-time heating (up to $5 \mathrm{~min}$ ) at $100^{\circ} \mathrm{C}$. Nevertheless, some honeys showed a significant reduction of TPC and total flavonoids after pasteurization (these values are summarized in Table 2), yet the antioxidant activity varied, depending on the assay employed in the analyses.

Besides the honey's botanical origin, the intensity of the thermal processing, such as the processing temperature and time, is also an essential factor affecting the antioxidant activity of honey. The study by Karabagias et al. (2018) reported that mild temperature increased antioxidant activity in all tested honeys. On the other hand, when honey was processed at $80^{\circ} \mathrm{C}$, the antioxidant activity decreased in some samples and increased in others. Further, the prolonged thermal processing at 50,70 , and $90^{\circ} \mathrm{C}$ for $12 \mathrm{~h}$ improved the antioxidant potential of honey by gradually increasing the antioxidant compounds (phenolic acids and flavonoids) and antioxidant activity (DPPH and FRAP) (Jahan et al., 2015). This may happen because heat promotes phenolic compounds' extraction (Chaikham \& Prangthip, 2015) but also the formation of Maillard reaction products (Brudzynski \& Miotto, 2011) and HMF (Ota et al., 2019). Melanoidins are high-molecular-mass components responsible for radical scavenging capacity. They are present in unheated honey, but their content increases during thermal processing, particularly at elevated processing temperature, at the Maillard reaction's advanced stage (Brudzynski, 2012). Brudzynski and Miotto (2011) have stated that the initial concentration of melanoidins in honey influences honey's antioxidant activity during thermal processing. They found that at a low initial concentration of melanoidins, the thermal processing at extreme temperature $\left(121^{\circ} \mathrm{C}\right.$ for $\left.30 \mathrm{~min}\right)$ accelerated the formation of new melanoidins and increased the antioxidant activity (ORAC values). In contrast, at high initial concentration, the radical scavenging activity decreased. Elamine et al. (2020) observed increased content of melanoidins at similar processing conditions $\left(120^{\circ} \mathrm{C}, 30 \mathrm{~min}\right)$. However, such extreme processing conditions darkened the honey. Depending on the assays employed to estimate the antioxidant activity (Table 2), the DPPH and ABTS free radical scavenging activity increased; but NO scavenging activity drastically decreased, indicating the reduced ability of the processed honey to scavenge this critical mediator of inflammation; and the chelating ability of honey removed after the thermal processing. 
The antioxidant activity of thermally processed honey can be reduced or enhanced. However, the changes in antioxidant activity during thermal processing depend primarily on honey's botanical and geographical origin and the temperature and duration of thermal processing (Pimentel-González et al., 2016). Prolonged thermal processing and processing at high temperatures $\left(\geq 80^{\circ} \mathrm{C}\right)$ can enhance the antioxidant potential of honey, probably due to the compensation of loss of natural antioxidants by the formation of non-nutrient antioxidants, such as the Maillard reaction products (Jahan et al., 2015).

\subsubsection{Changes in antibacterial activity of honey}

Due to the increased antibiotic resistance among pathogens, many infections become harder to treat as the antibiotics used to treat them become less effective. The World Health Organization (WHO) acknowledged that a post-antibiotic era, in which common infections and minor injuries can kill, is a real possibility for the $21^{\text {st }}$ century (World Health Organization, 2014). Honey has been recently investigated due to its potential to aid fight against multi-resistant infectious agents (CombarrosFuertes et al., 2020). Moreover, microbial resistance to honey has never been reported, making the honey an up-and-coming antimicrobial agent against the infection of antibiotic-resistant bacteria (Mcloone et al., 2016). Remarkably, in vitro research showed that combinations of honey with antibiotics have synergistic and additive actions against bacterial biofilm (Nolan et al., 2019). A recent study by Oliveira et al. (2017) demonstrated that combined delivery of honey with phages is a promising antimicrobial alternative, particularly in the treatment of chronic wound infections with Escherichia coli, and can be an alternative for other bacterial strains that do not respond to antibiotic therapy (Oliveira et al., 2017).

Nowadays, products based on medical-grade honey, mainly manuka honey, are utilized for topical treatment of infected wounds (Scepankova et al., 2017). However, there is a plethora of scientific papers reporting in vitro as well in vivo antibacterial activity of several types of honey, equivalent or better than the medical-grade manuka honey, being those tualang honey, heather honey, kanuka honey, buckwheat honey, and others (Bucekova et al., 2020; Dezmirean et al., 2015; Mcloone et al., 2016; Semprini et al., 2019). The antimicrobial efficacy of these honeys is primarily due to the hydrogen peroxide $\left(\mathrm{H}_{2} \mathrm{O}_{2}\right)\left(\mathrm{H}_{2} \mathrm{O}_{2}\right.$-dependent activity honey) (Oliveira et al., 2017), whereas manuka honey displays significant antibacterial effects due to the presence of non-peroxide compounds, such as methylglyoxal (MGO) and phenolic compounds (non-peroxide activity honey) (Girma et al., 2019).

Only a few reports focused on honey's thermal stability regarding its antimicrobial activity during thermal processing. A recent study carried out by Kato et al. (2021) investigated the changes in the antibacterial essential compound $\mathrm{MGO}$ in manuka honey during heating at $90^{\circ} \mathrm{C}$. The results demonstrated that the level of MGO gradually decreased with prolonged heating time (up to $120 \mathrm{~min}$ ), being the loss of MGO more than 55\% after $2 \mathrm{~h}$. Moreover, thermal processing also caused a significant decrease of 2 ' methoxyacetophenone (MAP), one of the most important markers for the official definition of manuka honey in New Zealand (Kato et al., 2021).

Chen et al. (2012) have examined the effect of commercial thermal processing $\left(45^{\circ} \mathrm{C} / 8 \mathrm{~h}\right.$ with filtering) on honey derived from three native Australian floral sources associated with $\mathrm{H}_{2} \mathrm{O}_{2}$-dependent activity. Four from a total of 17 unprocessed honey samples showed antibacterial activity against $S$. aureus. The mild thermal processing $\left(45^{\circ} \mathrm{C} / 8 \mathrm{~h}\right)$ significantly reduced the antibacterial activity against $S$. aureus in three red stringybark honey, dropping activity from 2.7 to $7.2 \%$ of phenol equivalence, and inhibited the antibacterial activity in red stringybark-canola blend honey. Similarly, most processed honey also had lower antifungal activity against $C$. albicans than the unprocessed honey.

Bucekova, Juricova, Monton, et al. (2018) investigated the effect of mild $\left(45^{\circ} \mathrm{C}\right)$ and moderate $\left(55^{\circ} \mathrm{C}\right)$ liquefying conditions (for 8,24 , and $48 \mathrm{~h}$ ) on the honey antibacterial compound, such as bee defensin-1 content and $\mathrm{H}_{2} \mathrm{O}_{2}$ production in crystalized rapeseed (Brassica napus) honey. The $\mathrm{H}_{2} \mathrm{O}_{2}$ production significantly decreased (at $55^{\circ} \mathrm{C}$ after $48 \mathrm{~h}$ ), whereas defensin-1 showed only a slightly decreasing trend. Also, the glucose-oxidase enzyme significantly decreased at $55^{\circ} \mathrm{C}$ for $8 \mathrm{~h}$. Kretavičius et al. (2010) documented that glucose-oxidase activity in de-crystalized buckwheat honey decreased at higher temperature intervals, such as at $55-70^{\circ} \mathrm{C}$. Although the thermal processing has a deleterious effect on honey's antibacterial components, the study by Bucekova, Juricova, Di Marco, et al. (2018) reported no significant changes in antibacterial activity toward $S$. aureus and $P$. aeruginosa between unprocessed and processed honey at 45,55 , and $65^{\circ} \mathrm{C}$.

Pimentel-Gonzalez et al. (2017) investigated the effect of thermal processing at temperatures up to $80^{\circ} \mathrm{C}(45 \mathrm{~min})$ on the antibacterial activity of multifloral honey from different Mexico regions. Honey exposed to a high processing temperature of $80^{\circ} \mathrm{C}$ for $45 \mathrm{~min}$ did not show significant changes in the antibacterial activity against Bacillus subtills, Listeria monocytogenes, Pseudomonas aeruginosa, and Salmonella typhimurium. However, different behavior in antibacterialactivity against $S$. aureus 
and E. coli was found. The antibacterial activity against $S$. aureus and $E$. coli enhanced in all honey processed at temperatures up to $60^{\circ} \mathrm{C}$. However, a higher processing temperature caused a reversed behavior, being the maximum decrease of the antibacterial activity at $80^{\circ} \mathrm{C}$.

Majkut et al. (2021) found that increasing temperature to $42^{\circ} \mathrm{C}$ for $15 \mathrm{~min}$ did not change the antibacterial activity of multifloral, lime, rapeseed, and buckwheat honey against most Gram-positive and Gram-negative bacteria (S. aureus, E. faecalis, E. coli, and P. aeruginosa). However, at $62^{\circ} \mathrm{C}$, most of the tested honeys exhibited a loss of antibacterial properties, and at $100^{\circ} \mathrm{C}$ total loss of bactericidal properties was observed in all tested honeys. Moreover, prolonged thermal processing $(2 \mathrm{~h})$, even at nonexcessive temperatures (i.e., $42^{\circ} \mathrm{C}$ ), drastically reduced antibacterial properties in all tested honeys.

The antimicrobial activity of honey decreases by the application of conventional thermal processing. Mainly, prolonged and/or high-temperature processing conditions can cause loss of honey's antimicrobial activity, yet depending on the honey's floral sources and the kind of bacteria they inhibit (Jahan et al., 2015). Therefore, studies indicated that honey's curative use as an antimicrobial is recommended with no or limited thermal treatment (Majkut et al., 2021). Recently, there is a demand for honey's antibacterial activity to be used as an additional quality standard parameter reflecting its biological properties (Bucekova et al., 2020).

\section{3 | EMERGENT TECHNOLOGIES FOR RAW HONEY PROCESSING}

In this section, the use of emergent thermal and nonthermal food processing technologies in combination with moderate/high temperatures, for honey decontamination, and the main effects on the overall quality parameters are presented in Table 3-6 and discussed in this section.

\section{1 | High-pressure processing}

High-pressure processing (HPP) is a nonthermal food pasteurization technique that uses elevated hydrostatic pressures for short periods (commercially up to $600 \mathrm{MPa}$ and a few minutes) to inactivate both spoilage and pathogenic vegetative microorganisms, as well as to inactivate some enzymes. As no heat is applied, most of the nutritional value remains unchanged, mainly by keeping thermolabile compounds on foods. HPP is reported to have little to no impact on microbial loads of foods with low water activity due to the protective effect of microorganisms (Pinto et al., 2020), which can be surpassed by honey dilution (Akhmazillah et al., 2017).

Nevertheless, when combined with moderate/high temperatures, it is possible to reduce the microbial loads of raw manuka honey below detection limits, as observed by Akhmazillah et al. (2012) for hydrostatic pressures of $300 \mathrm{MPa}$ onward and temperatures higher than $30^{\circ} \mathrm{C}$.

The application of HPP in honey can enhance several biochemical aspects, namely, the TPC, which will increase antioxidant activity and, consequently, antimicrobial activity, which seems to be more pronounced at higher pressures, with temperature having a minor effect (Akhmazillah et al., 2013; Akhmazillah \& Farid, 2015). Considering that the current HPP equipment is operated at and below room temperatures $\left(4-25^{\circ} \mathrm{C}\right.$, water inlet temperature), nonthermal HPP could be an exciting approach to enhance honey's bioactivity for market niches or other biomedical and cosmetic applications.

The main effects of nonthermal HPP and its combination with moderate/high temperatures are displayed in Table 3. As previously mentioned, the formation of HMF is a consequence of thermal processing and long storage periods, being an indicator of honey quality. HPP seems to have a positive effect on HMF formation, as the combination of pressures ( $\leq 330 \mathrm{MPa}$ ) with high temperatures usually results in lower HMF levels compared to thermal processing alone, as observed by Önür et al. (2018) for Turkish honey (canola, cotton, and sunflower) and by Akhmazillah and Farid (2015). The authors stated that dwell time has a more significant impact on HMF formation than the pressure levels, that is, longer processing times increase the formation of HMF for a given pressure level, whereas HMF levels present lower variations when a processing time is set, and the pressure level varies. This fact can be explained by the inhibition exerted by HPP on Maillard reactions, which normally occur at high temperatures. Also, the amount of oxygen in the matrix/package to be processed seems to increase the formation of brown pigments due to the formation of melanoidins (Isaacs \& Coulson, 1996), so this is a parameter to be considered when setting up for HPP-based applications with honey.

The color of honey is immensely affected by thermal processing due to brown pigments' formation caused by Maillard and caramelization reactions. As HPP usually results in lower levels of HMF, an intermediate in the Maillard reaction's chain, it will have a lower impact in processed honey compared to conventional thermal processing, as observed by Akhmazilah Fauzi et al. (2014); notwithstanding, high dwell times tend to decrease color parameters of honey, which is related to the increase of HMF. 

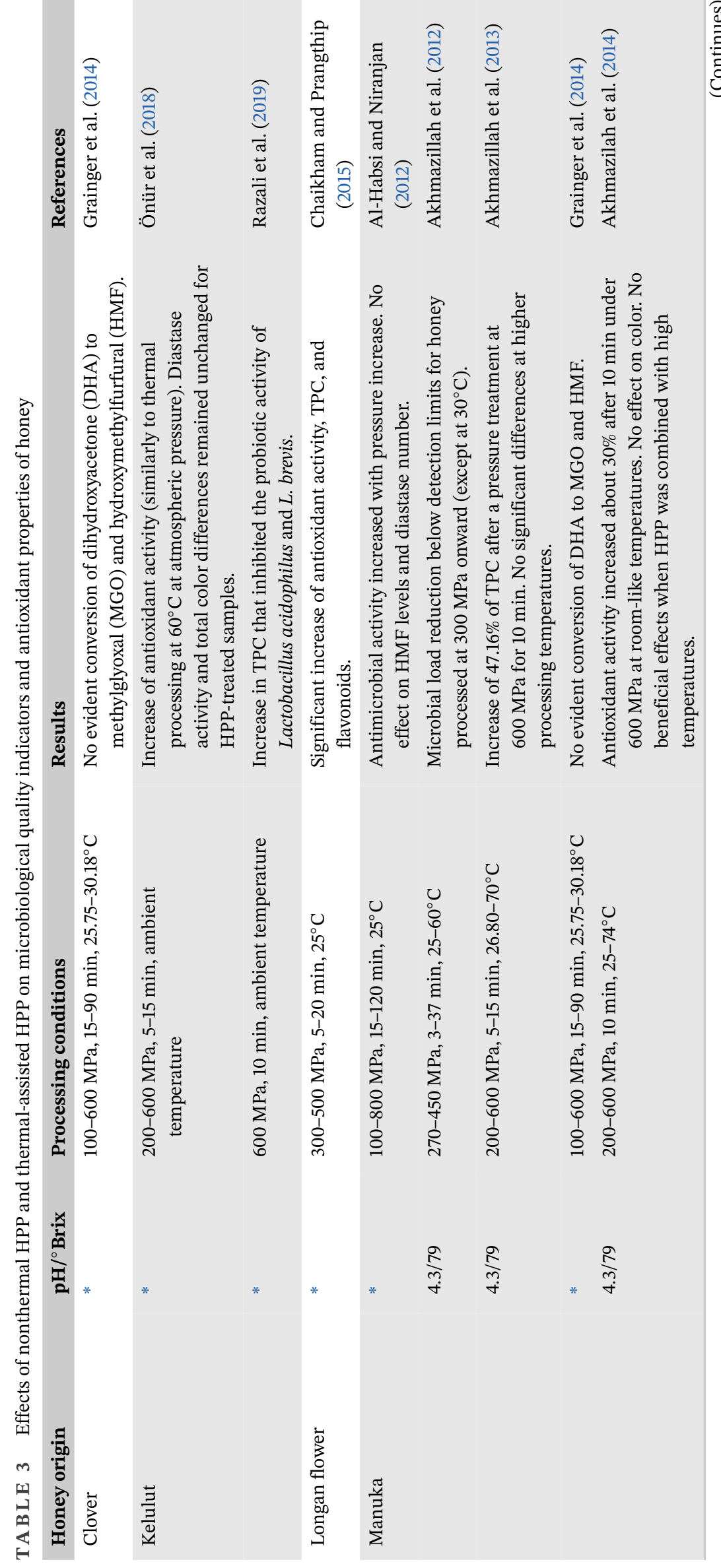


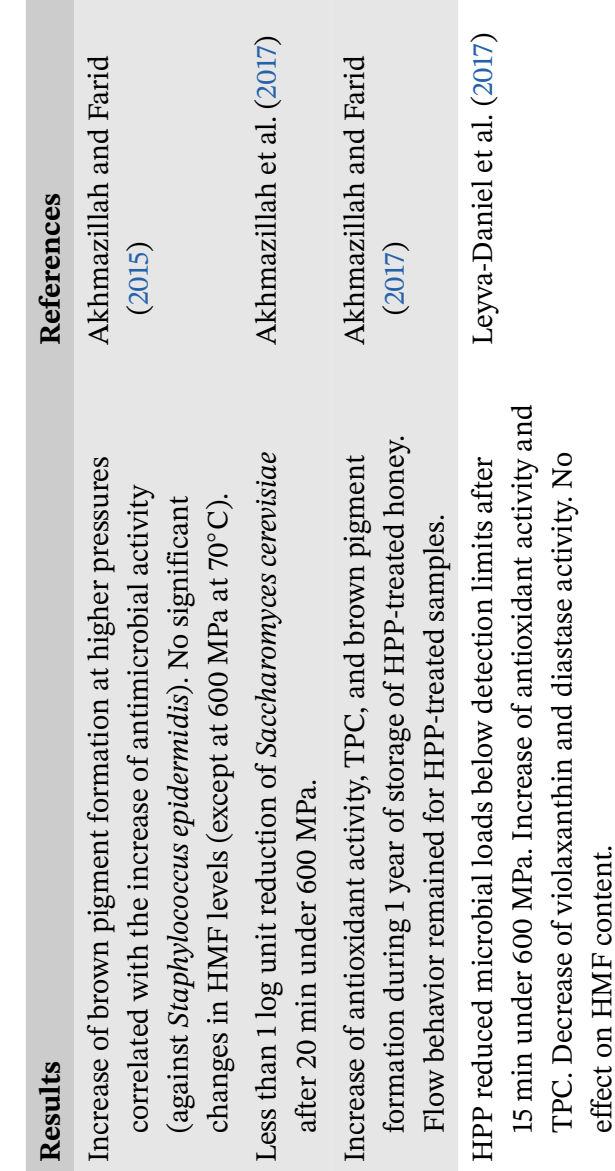

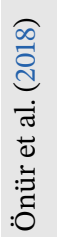

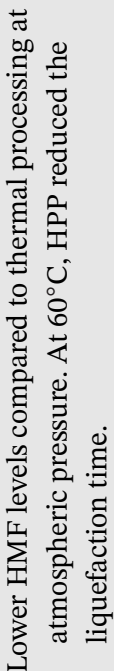

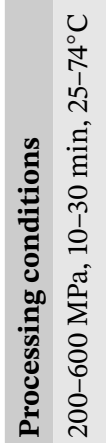
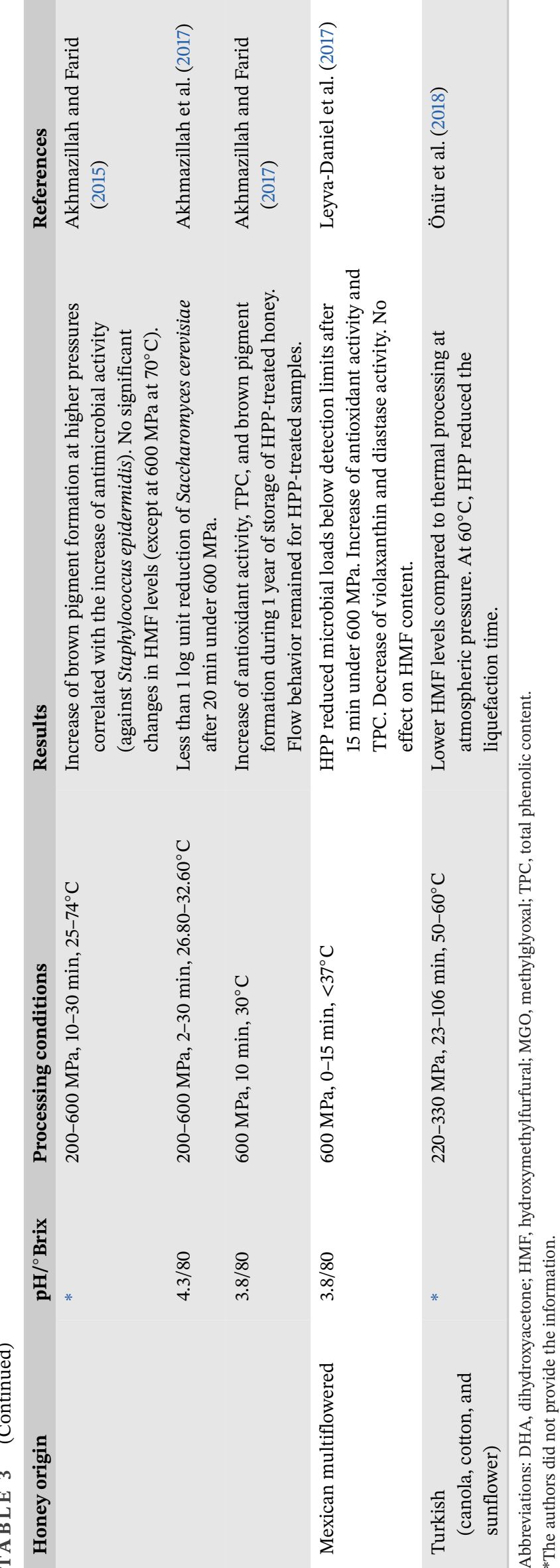

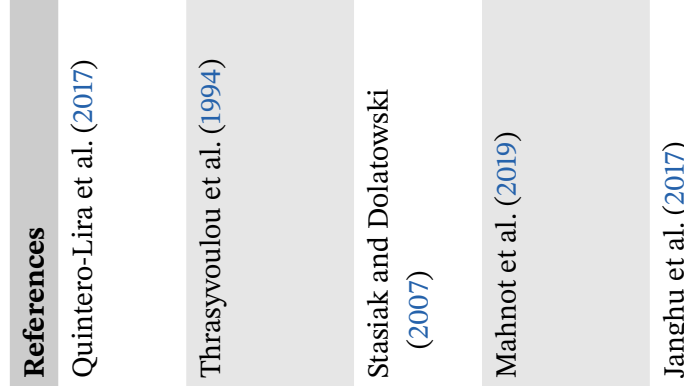

Iิ
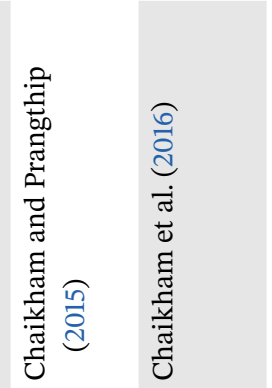

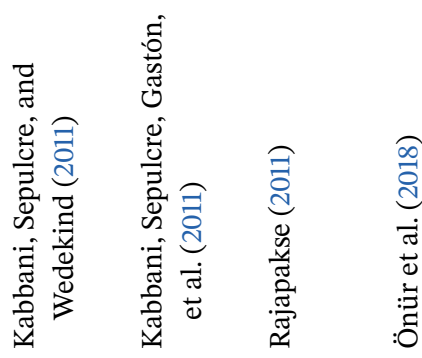

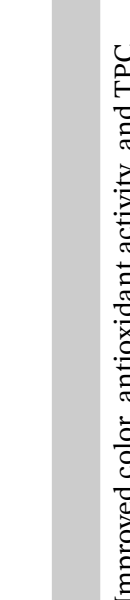

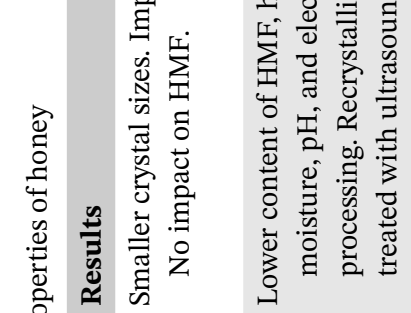

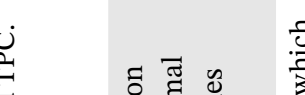

동

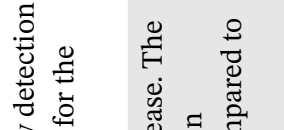

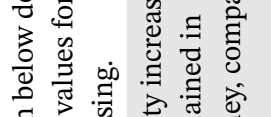

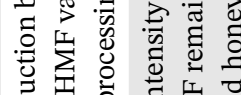

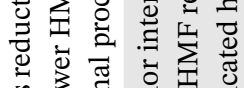

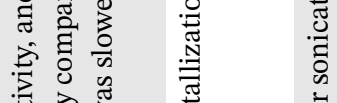

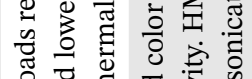

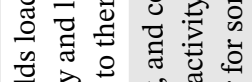

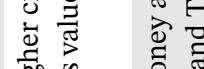

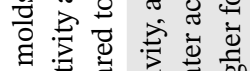

要 范

¿

ర్ี

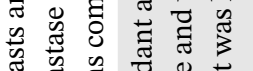

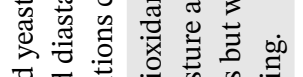

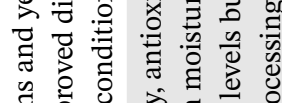

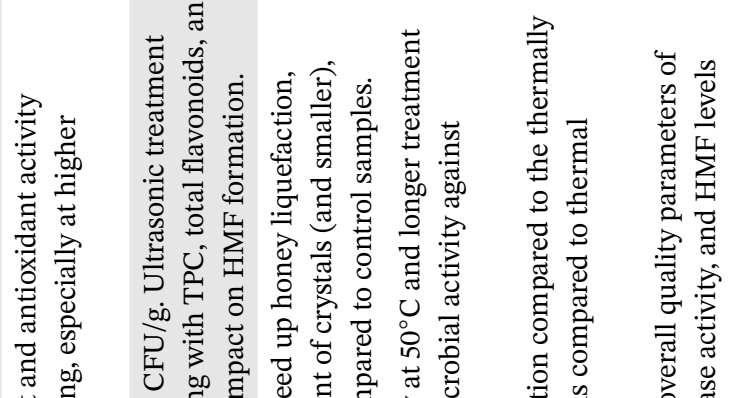

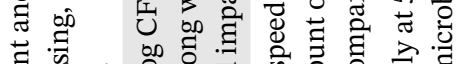

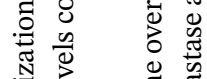

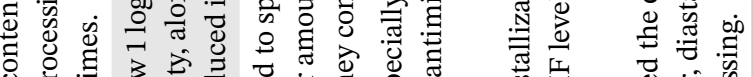

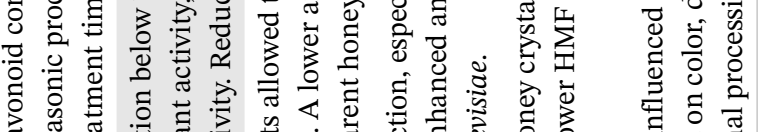
范苛 范

突

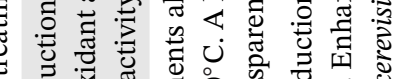

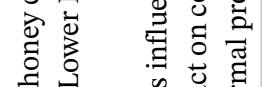

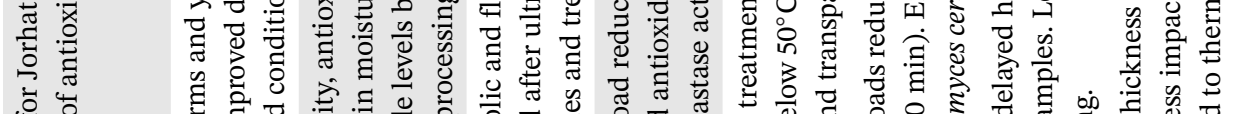
范

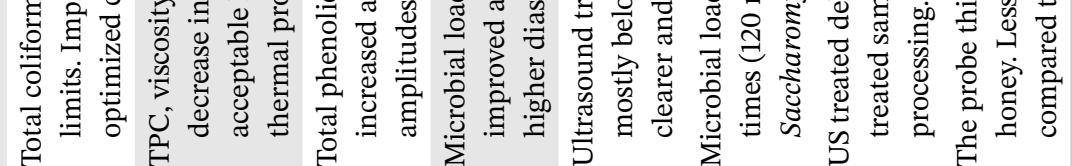

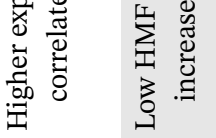

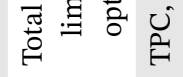

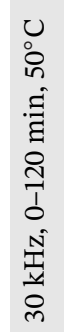

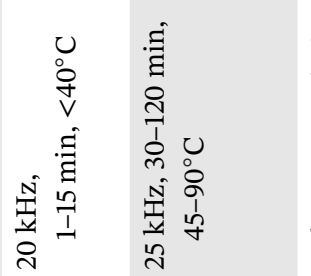

:

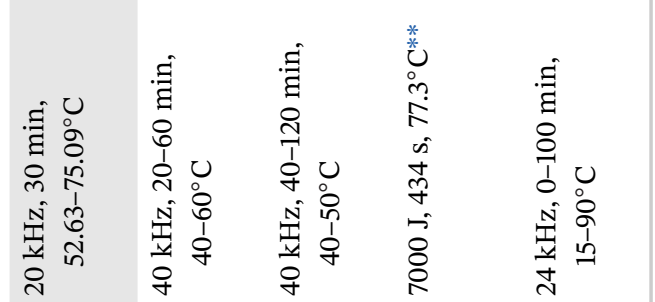
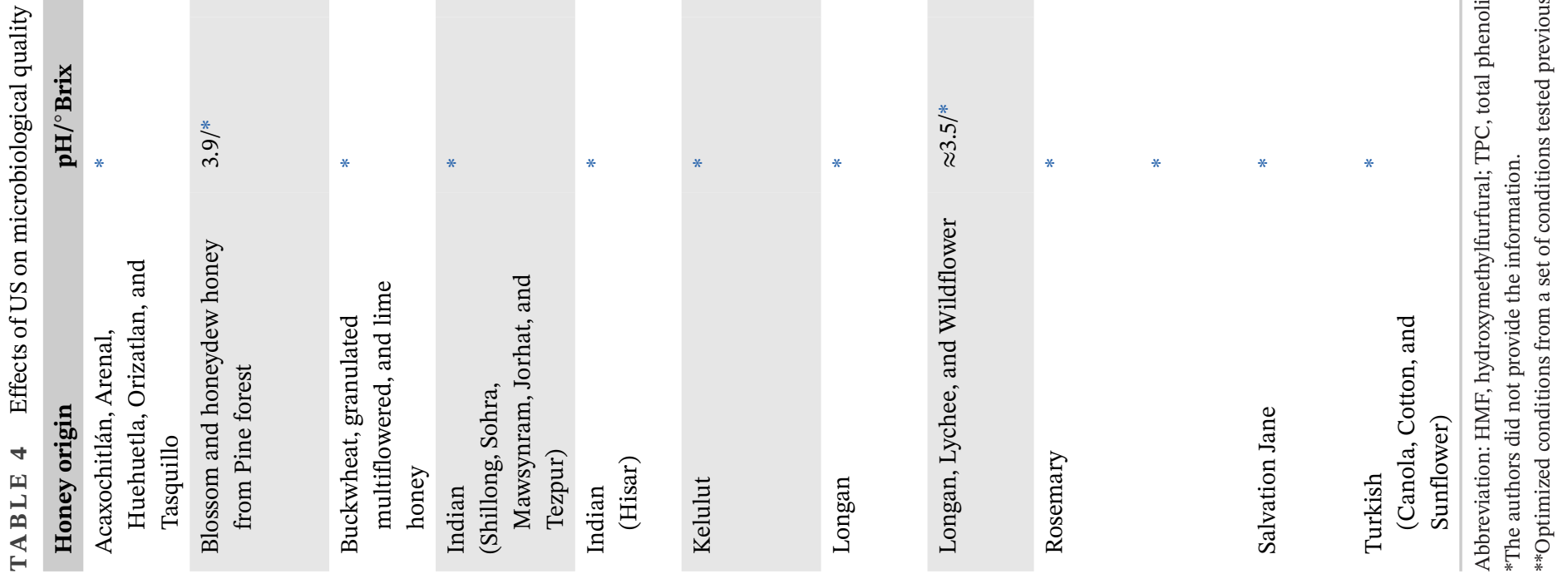


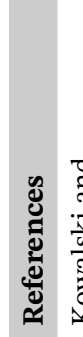

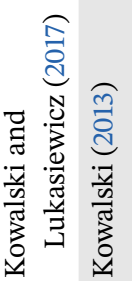

㩊

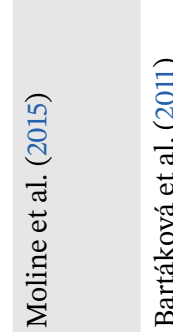

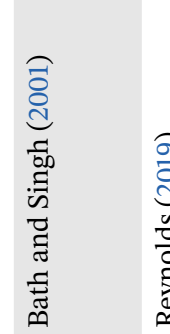
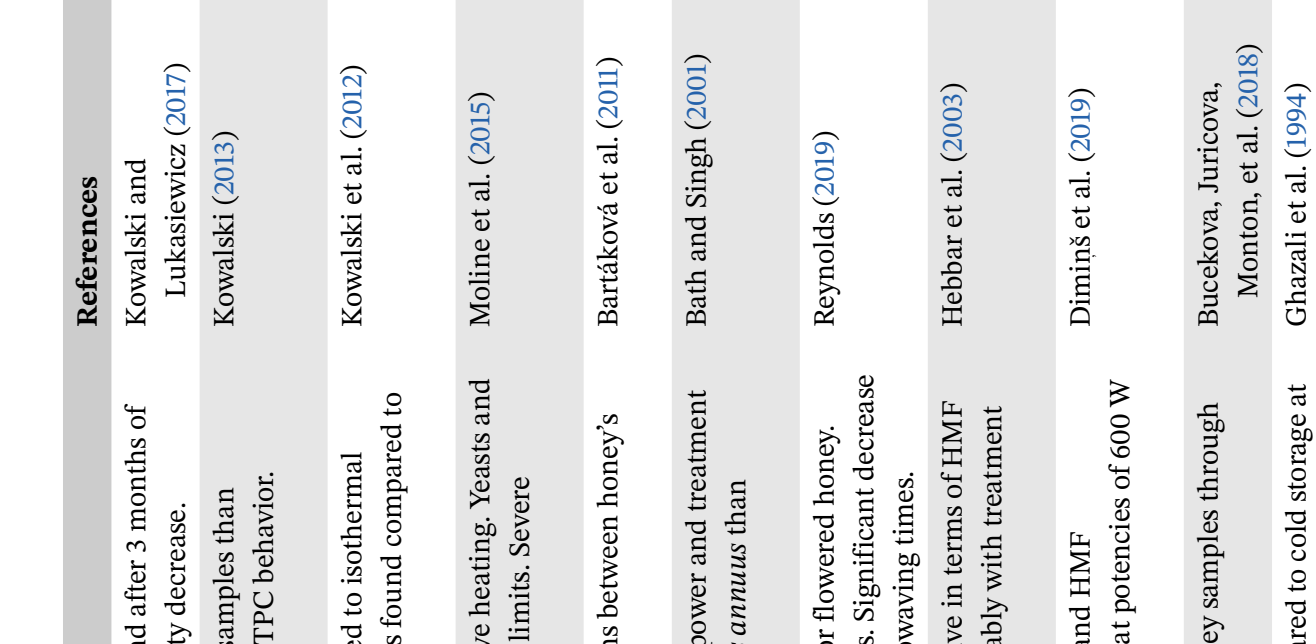

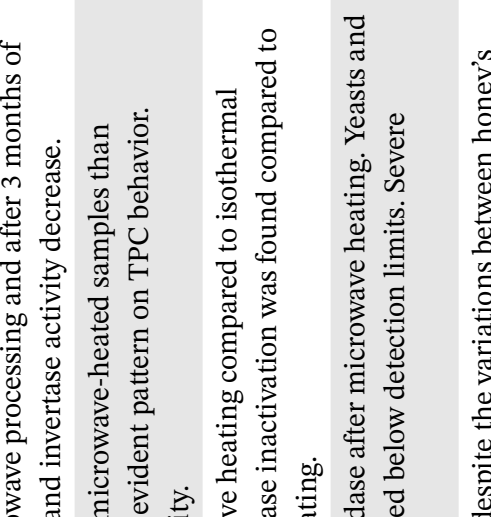

ब্ँ

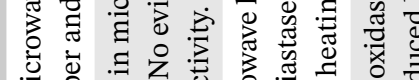

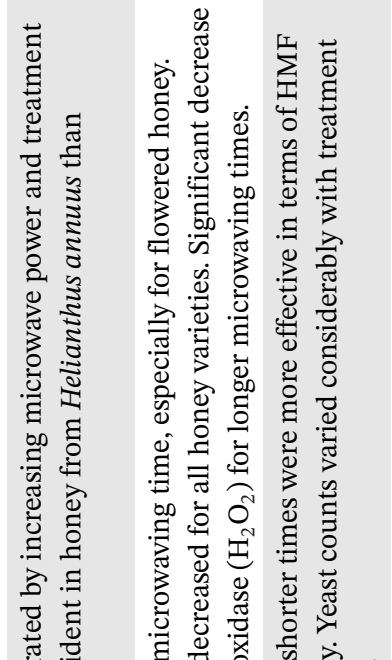

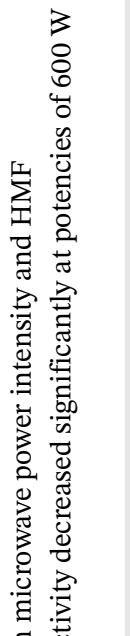

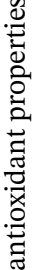

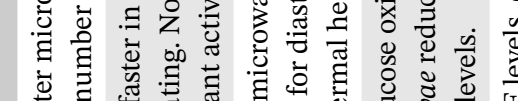

$\frac{\dot{n}}{\infty} \frac{\infty}{d}$

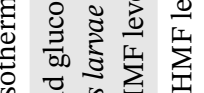

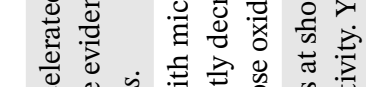

$\therefore$ ष्च

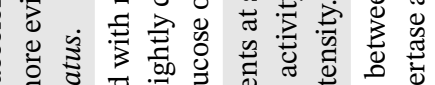

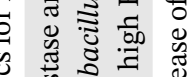

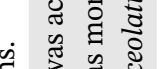

च

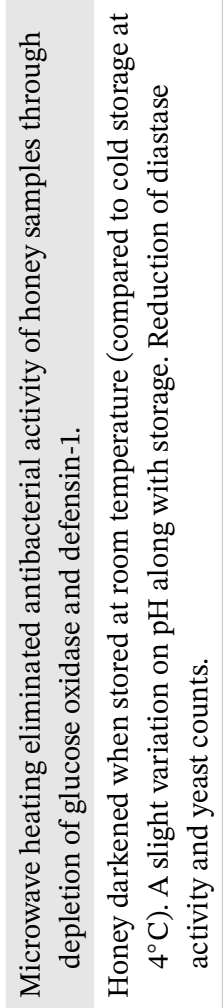

:
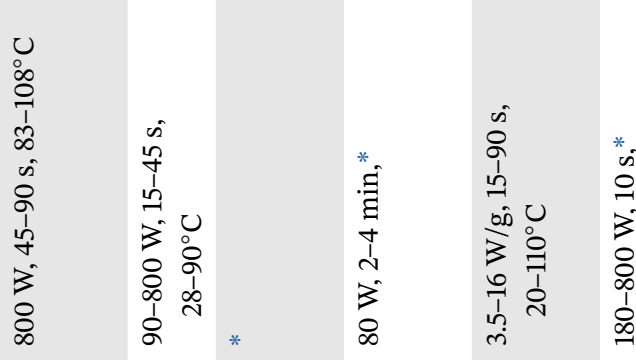


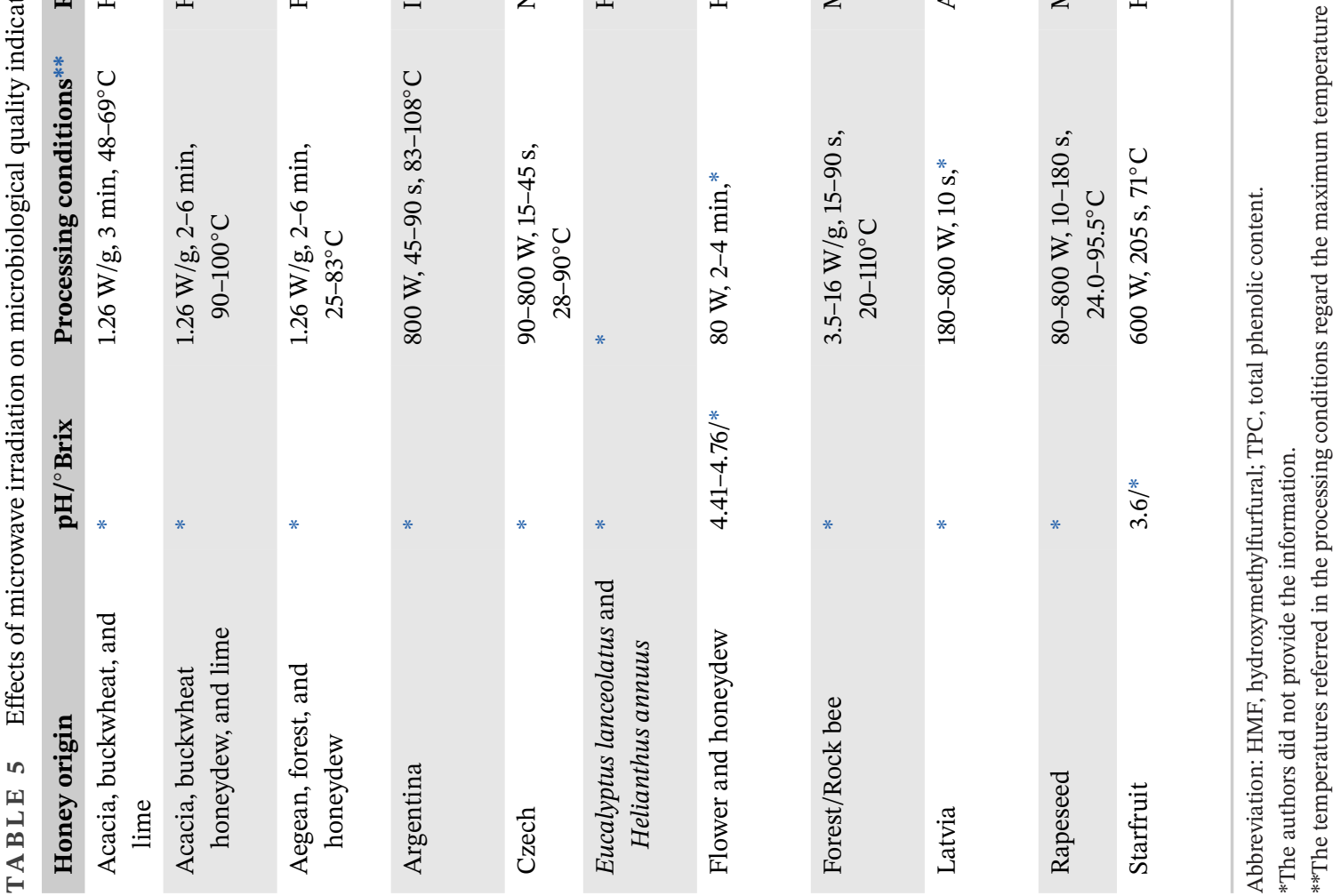


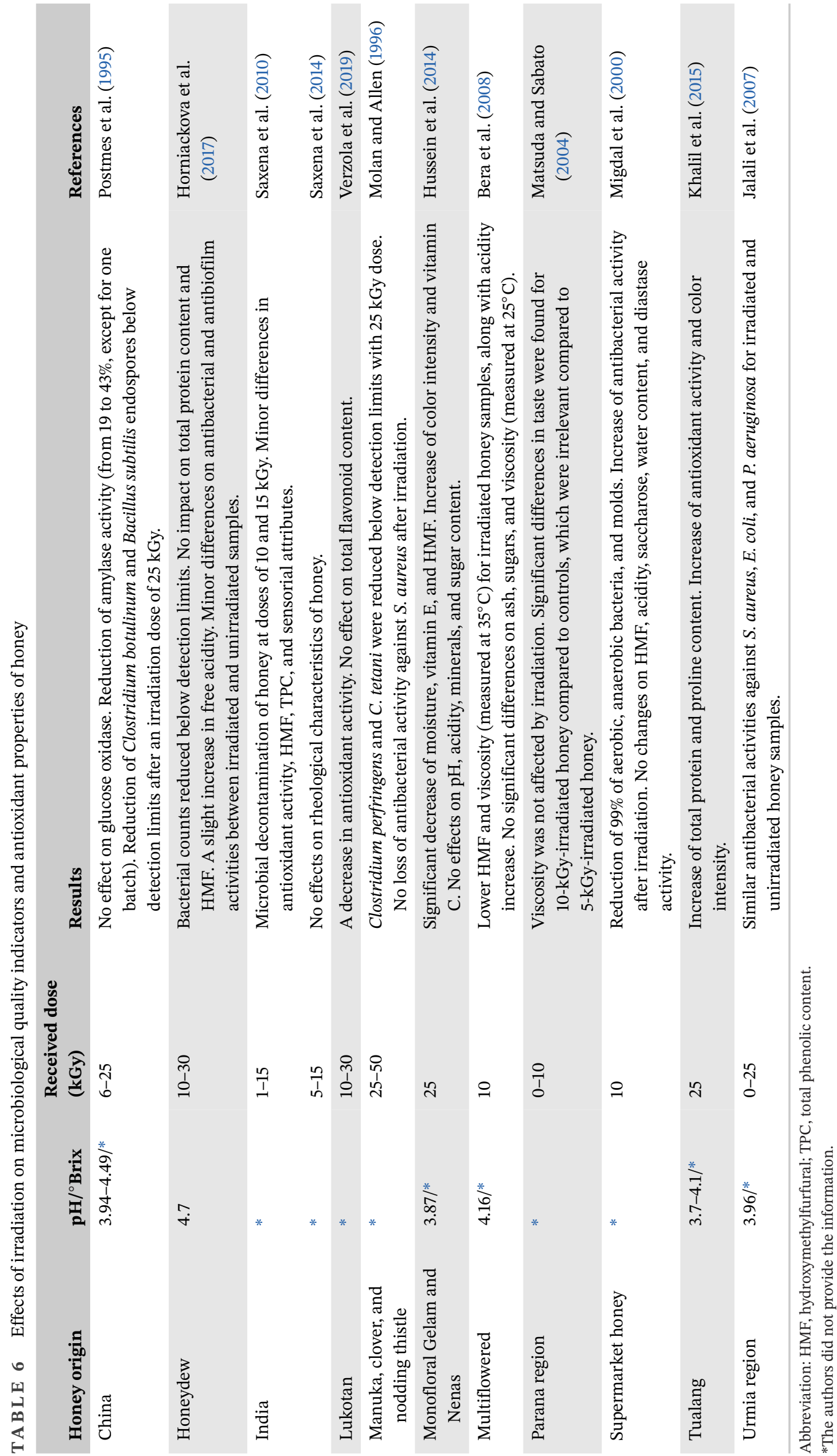


Diastase, an enzyme considered a quality indicator of honey, seems to be generally unaffected by HPP (at roomlike temperatures), as reported by Önür et al. (2018) and AlHabsi and Niranjan (2012) for kelulut and manuka honey, whereas Leyva-Daniel et al. (2017) reported a decrease in DA in Mexican honey. These results may be related to the honey variety (origin), which will inherently influence honey's chemical composition.

\section{2 | Ultrasounds}

The primary use of high-intensity ultrasounds (in the range of $10-1000 \mathrm{~W} / \mathrm{cm}^{2}$ and a frequency of $20-100 \mathrm{kHz}$ ) in food processing aims microbial inactivation by disruption of the cell walls of bacteria and fungi (Yao et al., 2020; Yu et al., 2020), as a consequence of the cavitation process.

The first known report of ultrasound processing of honey is attributed to Thrasyvoulou et al. (1994), who reported the possibility of using ultrasounds for honey liquefaction compared to conventional thermal liquefaction, with the advantage of lower HMF content and higher DA, thus resulting in honey with higher quality. The authors also reported that the sonication process slowed down honey recrystallization. Indeed, especially when combined with mild temperatures, honey liquefaction can be accelerated by ultrasonic treatments (Kabbani, Sepulcre, \& Wedekind, 2011). Interestingly, after the sonication processes, the recrystallization presents smaller crystal sizes compared to those thermally liquefied (Kabbani, Sepulcre, \& Wedekind, 2011; Quintero-Lira et al., 2017).

When it comes to the feasibility of ultrasounds as a decontamination technique, it depends on the operation setup (probe diameter), temperature, and treatment time. Indeed, higher temperatures and treatment times and bigger probe diameters seem to improve microbial load reduction in honey (Chaikham et al., 2016; Kabbani, Sepulcre, Gastón, et al., 2011; Önür et al., 2018); nevertheless, the application of ultrasounds combined with high temperatures can have an amplified detrimental effect when compared to thermal treatment alone (Chong et al., 2017). For so, when considering the use of ultrasounds for honey processing, a balance must be achieved between the desirable microbial load inactivation and the inherent impact that the processing conditions will have on the sonicated honey.

The main effects of ultrasounds and their combination with moderate/high temperatures are displayed in Table 4.

\section{3 | Microwave}

Microwaves consist of electromagnetic waves that fit in frequencies between $300 \mathrm{MHz}$ and $30 \mathrm{GHz}$, corresponding to the region between infrared and radio frequencies in the electromagnetic spectrum (Chandrasekaran et al., 2013). The feasibility of microwave heating relies on the food product's moisture content, being more feasible for foods with high water content. Indeed, microwaves can penetrate the food product to a certain depth and interact with polar molecules (such as water), which are quickly heated due to the molecular friction generated by dipolar rotation in the presence of an alternating electric field. Dissolved sugars are also susceptible to microwave irradiation, making honey (due to its water content and high amounts of dissolved sugar) a suitable candidate for microwave processing to increase safety (due to the temperatures reached, allowing to inactivate pertinent vegetative pathogenic microorganisms) and bioactivity (by increasing the content of melanoidins) (Subramanian et al., 2007).

The first known report covering the application of microwave processing in honey is attributed to Ghazali et al. (1994). They reported a decrease in yeast counts and lower DA after honey microwaving at $600 \mathrm{~W}$ for $205 \mathrm{~s}$ (the temperature reached $71^{\circ} \mathrm{C}$ at the end of the microwaving process), along with accelerated darkening for honey afterward stored at room temperature, compared to that kept at $4^{\circ} \mathrm{C}$ (which did not darken), possibly due to browning reactions.

The heating process by microwaves occurs quickly than conventional isothermal heating, and it allows a lower impact on HMF values of the processed honey due to the lower times required to achieve a specific temperature set point. Nevertheless, the HMF formation in honey seems to increase at higher potencies for the same processing time, because it results in higher final temperatures and lower diastase activities (Kowalski, 2013; Kowalski et al., 2012).

The feasibility of microwave processing for honey decontamination depends on honey origin, potency, treatment time, and achieved temperature. More intense treatments (at higher potencies, longer treatment times, and higher temperatures) seem to be more effective in inactivating honey's indigenous microorganisms (Bath \& Singh, 2001; Hebbar et al., 2003).

An additional effect of microwave heating seems to be the loss of antimicrobial activity, mainly due to the inactivation of enzymes, such as glucose oxidase, which play a significant role in honey's antimicrobial activity (Bucekova, Juricova, Monton, et al., 2018; Moline et al., 
2015). Other effects of microwave heating are summarized in Table 5.

\subsection{Irradiation}

This methodology consists of an in-package (or not) sterilization procedure, primarily when performed at higher doses (above $10 \mathrm{kGy}$ ), wherein ionizing radiation in the form of gamma-rays, X-rays, or electronic beams penetrates the food product and, consequently, microorganisms. The radiation then penetrates the cells and creates DNA dimers, which will hurdle vital cellular functions such as protein synthesis and DNA replication. It can also target the lipids from the membranes by oxidizing them. Irradiation is generally recognized as a safe practice to decontaminate food products (Feliciano, 2018).

The first known report on gamma radiation for honey decontamination was performed by Huhtanen (1991). In this preliminary study, honey cans irradiated with ${ }^{137} \mathrm{Cs}$ at a dose of $6.0 \mathrm{kGy}$ reduced $C$. botulinum endospores less than $0.70 \log$ units and Bacillus subtilis between 1.5 and 1.8 log units in honey, compared to complete inactivation of both spores when suspended in water. The authors stated that higher doses would be needed to achieve the same microbial inactivation levels due to the radio-protective effect conferred by ascorbic acid, fumarate, and glutamate present in honey.

The success of irradiation is widely reported, especially at 10-15 kGy for vegetative microorganisms (Saxena et al., 2010) and at $25 \mathrm{kGy}$ onward for bacterial spores (Molan \& Allen, 1996; Postmes et al., 1995). Despite the lack of studies covering the effects of irradiation against fungi spores in honey, it is expected that the same dose for bacterial spores' inactivation is also suitable for fungi spores, as they are generally more sensitive than bacterial spores (Pinto et al., 2020).

The impact of irradiation in honey's rheological behavior is entirely dependent on honey origin and temperature of analysis. Indeed, Matsuda and Sabato (2004) reported no viscosity changes in Parana honey after being irradiated at 5 and $10 \mathrm{kGy}$, whereas Bera et al. (2008) reported viscosity decrease (measured at $35^{\circ} \mathrm{C}$ ) in multiflowered honey after receiving a dose of $10 \mathrm{kGy}$, but, if measured at $25^{\circ} \mathrm{C}$, it was similar to unirradiated honey, clearly showing that temperature is an essential parameter to control upon viscosity measurement.

The effects of irradiation in raw honey regarding physicochemical and enzymatic parameters, antioxidant activity, HMF formation, among others are entirely dependent upon honey origin (and composition, as expected), as seen in Table 6.

\section{5 | Ultraviolet light}

Literature covering the application of ultraviolet light (UV light) for nonthermal pasteurization of honey is very scarce. Either way, some studies are reporting the effects of pulsed and continuous UV light treatments on raw honey.

Hillegas and Demirci (2003) evaluated the effectiveness of pulsed UV light against Clostridium sporogenes endospores inoculated in clover honey, varying the number of the UV light pulses, treatment time, the distance between the UV light source and the honey, and the depth of honey. The authors reported a reduction of $89.4 \%$ in endospore counts after 540 pulses for $180 \mathrm{~s}$ at a distance of $20 \mathrm{~cm}$ from the UV light source with a honey depth of $8 \mathrm{~mm}$. It was also observed that the treatment time and the distance between the honey and the UV light source were the main parameters with more influence on endospore inactivation. Different results were obtained by Roig-Sagués et al. (2018), who studied the effects of UV light in E. coli and endospores of B. subtilis and C. sporogenes and reported $5 \log$ units' inactivation of E. coli and approximately 2.5 log units' reduction of both endospores' species. The authors also evaluated the effects of short exposition time to UV light ( 4.5 to $36.0 \mathrm{~J} / \mathrm{ml}$, from 15 to $120 \mathrm{~s}$, respectively) and observed higher color variations at higher exposition times, attributing this to the temperature increase. Besides, HMF levels decreased proportionally to the UV light received dose, being lower compared to control samples (untreated honey), with the authors being unable to provide a possible explanation for this fact due to the lack of literature in this sense. A possible explanation for this observation can be stated considering the increase of color variations observed at higher UV light doses due to the formation of melanoidins, decreasing the concentration of HMF.

In another study, Fit et al. (2014) evaluated UV light feasibility to improve the antibacterial activity of four honey types (acacia, lime, sunflower, and multifloral). They observed that, after UV light treatment for $1 \mathrm{~h}$, the antibacterial activity increased against $S$. aureus and $B$. cereus, along with lower values of HMF compared to thermal processing $\left(50,70\right.$, and $100^{\circ} \mathrm{C}$ for $\left.30 \mathrm{~min}\right)$.

In addition, the use of UV light for honey decontamination can remove pesticides from honey (Marghtas et al., 2011), by photodegradation.

\section{4 | CONCLUSION}

Honey processing is a critical step when it comes to ensuring its quality and safety. Intense thermal processing can significantly change the nutritional features of this 
natural product. The use of (non)thermal emergent processing technologies for honey processing is a topic of interest, considering their capacity of preserving or even enhancing antioxidant and antimicrobial activity. Although thermal emergent processing technologies allow a more homogeneous and quicker heat process, nonthermal processing technologies allow obtaining a more rawliker food product, as most chemical changes induced by thermal processing (such as diastase and glucose oxidase inactivation, honey crystallization) do not occur. In this sense, it is possible to improve the biological activities of honeys processed by nonthermal emergent technologies, considering the lower impact on phenolic compounds and enzymes. Further studies are needed to ascertain, at a higher extension and depth, the impact of such emergent technologies on the biological activity and microbial safety of honey and the integration of these technologies for the development of honey-based cosmetic and pharmaceutical applications.

\section{ACKNOWLEDGMENTS}

Thanks are due to the University of Aveiro and FCT/MCT for the financial support for the LAQV/REQUIMTE and CIMO research Units (FCT UID/QUI/50006/2020 and UIDB/00690/2020, respectively) through national funds and, where applicable, co-financed by the FEDER, within the PT2020 Partnership Agreement, and to the Portuguese NMR Network. The authors Hana Scepankova and Carlos A. Pinto would like to thank also FCT/MCT for the Ph.D. grants (SFRH/BD/88133/2012 and SFRH/BD/137036/2018).

\section{AUTHOR CONTRIBUTIONS}

Hana Scepankova and Carlos A. Pinto wrote the main manuscript and constructed the tables. Vanessa Paula was responsible for the literature compilation and correction of the references. Leticia Estevinho and Jorge A. Saraiva designed this study and reviewed the manuscript.

\section{CONFLICTS OF INTEREST}

The authors declare no conflicts of interest.

\section{O R C I D}

Hana Scepankova (10 https://orcid.org/0000-0001-62707595

Carlos A. Pinto (1) https://orcid.org/0000-0002-5742-706X Vanessa Paula (10 https://orcid.org/0000-0001-7281-8598 Letícia M. Estevinho (1D https://orcid.org/0000-0002-92491948

Jorge A. Saraiva (1) https://orcid.org/0000-0002-5536-6056

\section{REFERENCES}

Abedi, F., Ghasemi, S., Farkhondeh, T., Azimi-Nezhad, M., Shakibaei, M., \& Samarghandian, S. (2021). Possible potential effects of honey and Its main components against Covid-19 infection. DoseResponse, 19(1), 1-13. https://doi.org/10.1177/1559325820982423

Akhmazilah, N., Farid, M., \& Silva, F. V. M. (2014). Highpressure processing of manuka honey: Improvement of antioxidant activity, preservation of colour and flow behaviour. Food and Bioprocess Technology, 7, 2299-2307. https://doi.org/10.1007/ s11947-013-1204-7

Akhmazillah, F. N., \& Farid, M. M. (2015). High-pressure processing of Manuka honey: Brown pigment formation, improvement of antibacterial activity and hydroxymethylfurfural content. International Journal of Food Science \& Technology, 50, 178-185. https: //doi.org/10.1111/ijfs.12630

Akhmazillah, F. N., \& Farid, M. M. (2017). High pressure processed manuka honey: Change in nutritional and rheological properties over 1-year storage. Journal of Food Processing and Preservation, 41(4), e13085. https://doi.org/10.1111/jfpp.13085

Akhmazillah, F. N., Farid, M. M., \& Silva, F. (2017). An insight on the relationship between food compressibility and microbial inactivation during high pressure processing. Journal of Food Science and Technology, 54(3), 802-809. https://doi.org/10.1007/ s13197-017-2526-7

Akhmazillah, M. F. N., Farid, M. M., \& Silva, F. V. M. (2012). High pressure processing of honey: Preliminary study of total microorganism inactivation and identification of bacteria. Journal of Science and Technology, 4, 1-12.

Akhmazillah, M. F. N., Farid, M. M., \& Silva, F. V. M. (2013). High pressure processing (HPP) of honey for the improvement of nutritional value. Innovative Food Science \& Emerging Technologies, 20, 59-63. https://doi.org/10.1016/j.ifset.2013.06.012

Al-Habsi, N. A., \& Niranjan, K. (2012). Effect of high hydrostatic pressure on antimicrobial activity and quality of Manuka honey. Food Chemistry, 135(3), 1448-1454. https://doi.org/10.1016/j.foodchem. 2012.06.012

Almasaudi, S. (2021). The antibacterial activities of honey. Saudi Journal of Biological Sciences, 28(4), 2188-2196. https://doi.org/10. 1016/j.sjbs.2020.10.017

Aydogan-coskun, B., Coklar, H., \& Akbulut, M. (2019). Effect of heat treatment for liquefaction and pasteurization on antioxidant activity and phenolic compounds of Astragalus and sunflowercornflower honeys. Food Science and Technology, 40(3), 629-634. https://doi.org/10.1590/fst.15519Effect

Baglio, E. (2018). Overheating indexes and honey quality. In Chemistry and technology of honey production (pp. 23-40). Springer. https://doi.org/10.1007/978-3-319-65751-6_3

Bartáková, K., Dračková, M., Borkovcová, I., \& Lenka, V. (2011). Impact of microwave heating on hydroxymethylfurfural content in Czech honeys. Czech Journal Food Science, 29(4), 328336.

Bath, P. K., \& Singh, N. (2001). Effect of microwave heating on hydroxymethylfurfural formation and browning in Helianthus annuus and Eucalyptus lanceolatus honey. Journal of Food Science and Technology, 38(4), 366-368.

Belitz, H. D., Grosch, W., \& Schieberle, P. (2009). Food chemistry (4th revise). Springer-Verlag.

Bera, A., Almeida-Muradian, L. B., \& Sabato, S. F. (2008). Study of some physicochemical and rheological properties of irradiated honey. Nukleonika, 53(2), S85-S87.

Biluca, F. C., Betta, F. D., de Oliveira, G. P., Pereira, L. M., Gonzaga, L. V., Oliveira Costa, A. C., \& Fett, R. (2014). 5-HMF and 
carbohydrates content in stingless bee honey by CE before and after thermal treatment. Food Chemistry, 159, 244-249. http://doi. org/10.1016/j.foodchem.2014.03.016

Bogdanov, S. (2009). Harmonised methods of the International Honey Commission. Swiss Bee Research Centre.

Brudzynski, K. (2012). Honey melanoidins: Emerging novel understanding on the mechanism of antioxidant and antibacterial action of honey. In J. Majtan (Ed.), Honey: Current research and clinical applications (pp. 17-38). Nova Science Publishers.

Brudzynski, K., \& Miotto, D. (2011). The recognition of high molecular weight melanoidins as the main components responsible for radical-scavenging capacity of unheated and heat-treated Canadian honeys. Food Chemistry, 125(2), 570-575. https://doi.org/10. 1016/j.foodchem.2010.09.049

Bucekova, M., Bugarova, V., Godocikova, J., \& Majtan, J. (2020). Demanding new honey qualitative standard based on antibacterial activity. Foods, 9(9), 1263. https://doi.org/10.3390/foods9091263

Bucekova, M., Juricova, V., Di Marco, G., Gismondi, A., Leonardi, D., Canini, A., \& Majtan, J. (2018). Effect of thermal liquefying of crystallised honeys on their antibacterial activities. Food Chemistry, 269, 335-341. https://doi.org/10.1016/j.foodchem.2018. 07.012

Bucekova, M., Juricova, V., Monton, E., Martinotti, S., Ranzato, E., \& Majtan, J. (2018). Microwave processing of honey negatively affects honey antibacterial activity by inactivation of bee-derived glucose oxidase and defensin-1. Food Chemistry, 240, 1131-1136. https://doi. $\operatorname{org} / 10.1016 /$ j.foodchem.2017.08.054

Chaikham, P., Kemsawasd, V., \& Apichartsrangkoon, A. (2016). Effects of conventional and ultrasound treatments on physicochemical properties and antioxidant capacity of floral honeys from Northern Thailand. Food Bioscience, 15, 19-26. https://doi.org/10. 1016/j.fbio.2016.04.002

Chaikham, P., \& Prangthip, P. (2015). Alteration of antioxidative properties of longan flower-honey after high pressure, ultra-sonic and thermal processing. Food Bioscience, 10, 1-7. https://doi.org/10. 1016/j.fbio.2015.01.002

Chandrasekaran, S., Ramanathan, S., \& Basak, T. (2013). Microwave food processing-A review. Food Research International, 52(1), 243261. https://doi.org/10.1016/j.foodres.2013.02.033

Chen, C., Campbell, L. T., Blair, S. E., Carter, D. A., Da, P. I., \& Jr, S. (2012). The effect of standard heat and filtration processing procedures on antimicrobial activity and hydrogen peroxide levels in honey. Frontiers in Microbiology, 3(265), 1-8. https://doi.org/10. 3389/fmicb.2012.00265

Chong, K., Chin, N., \& Yusof, Y. (2017). Thermosonication and optimization of stingless bee honey processing. Food Science and Technology International, 23(7), 608-622. https://doi.org/10.1177/ 1082013217713331

Chua, L. S., Adnan, N. A., Abdul-Rahaman, N.-L., \& Sarmidi, M. R. (2014). Effect of thermal treatment on the biochemical composition of tropical honey samples. International Food Research Journal, 21(2), 773-778.

Codex Alimentarius. (2001). Revised codex standard for honey, standards and standard methods. Food and Agriculture Organization of the United Nations. http://www.codexalimentarius.net

Combarros-Fuertes, P., Estevinho, L. M., Dias, L. G., Castro, J. M., Tomás-Barberán, F. A., Tornadijo, M. E., \& Fresno-Baro, J. M. (2019). Bioactive components and antioxidant and antibacterial activities of different varieties of honey: A screening prior to clinical application. Journal of Agricultural and Food Chemistry, 67(2), 688-698. https://doi.org/10.1021/acs.jafc.8b05436

Combarros-Fuertes, P., Fresno, J. M., Estevinho, M. M., SousaPimenta, M., Tornadijo, M. E., \& Estevinho, L. M. (2020). Honey: Another alternative in the fight against antibioticresistant bacteria? Antibiotics, 9(11), 1-21. https://doi.org/10.3390/ antibiotics 9110774

Cozmuta, A. M., Cozmuta, L. M., Varga, C., Marian, M., \& Peter, A. (2011). Effect of thermal processing on quality of polyfloral honey. Romanian Journal or Food Science, 1(1), 45-52.

Czipa, N., Phillips, C. J. C., \& Kovács, B. (2019). Composition of acacia honeys following processing, storage and adulteration. Journal of Food Science and Technology, 56(3), 1245-1255. https://doi.org/10. 1007/s13197-019-03587-y

Dezmirean, D., Marghitas, L. A., Fit, N., Chirila, F., Gherman, B., Margaoan, R., Aurori, A., \& Bobis, O. (2015). Antibacterial effect of heather honey (Calluna vulgaris) against different microorganisms of clinical importance. Bulletin UASVM Animal Science and Biotechnologies, 72(1), 72-77. https://doi.org/10.15835/ buasvmcn-asb

Diminš, F., Mikelsone, V., Augšpole, I., \& Niklāvs, A. (2019). Microwave facilities for thermal treatment of honey. Key Engineering Materials, 800, 103-107. https://doi.org/10.4028/www. scientific.net/KEM.800.103

Doménech, E., Escriche, I., \& Martorell, S. (2010). Quantification of risk to company's incomes due to failures in food quality. Reliability Engineering and System Safety, 95(12), 1324-1334. https://doi. org/10.1016/j.ress.2010.06.009

Elamine, Y., Anjos, O., Estevinho, M. L., Lyoussi, B., Aazza, S., \& Miguel, M. G. (2020). Effect of extreme heat processing on the Moroccan Zantaz' honey antioxidant activities. Journal of Food Science and Technology, 57(9), 3323-3333. https://doi.org/10.1007/ s13197-020-04365-X

Erejuwa, O. O., Sulaiman, S. A., \& Wahab, M. S. A. (2014). Effect of honey and its mechanisms of action on the development and progression of cancer. Molecules, 19, 2497-2522. https://doi.org/10. 3390/molecules19022497

Escriche, I., Visquert, M., Juan-Borrás, M., \& Fito, P. (2009). Influence of simulated industrial thermal treatments on the volatile fractions of different varieties of honey. Food Chemistry, 112(2), 329-338. https://doi.org/10.1016/j.foodchem.2008.05.068

Escriche, I., Kadar, M., Juan-Borrás, M., \& Domenech, E. (2014). Suitability of antioxidant capacity, flavonoids and phenolic acids for floral authentication of honey. Impact of industrial thermal treatment. Food Chemistry, 142, 135-143. https://doi.org/10.1016/j. foodchem.2013.07.033

Eteraf-oskouei, T., \& Najafi, M. (2013). Traditional and modern uses of natural honey in human diseases: A review. Iranian Journal of Basic Medical Sciences, 16, 731-742. https://www.ncbi.nlm.nih. gov/pmc/articles/PMC3758027/

European Commission. (2002). Opinion of the scientific committee on veterinary measures relating to public health on honey and microbiological hazards. http://ec.europa.eu/food/fs/sc/scv/ out53_en.pdf

Fallico, B., Zappalà, M., Arena, E., \& Verzera, A. (2004). Effects of conditioning on HMF content in unifloral honeys. Food Chemistry, 85(2), 305-313. https://doi.org/10.1016/j.foodchem.2003.07.010 
Feliciano, C. P. (2018). High-dose irradiated food: Current progress, applications, and prospects. Radiation Physics and Chemistry, 144, 34-36. https://doi.org/10.1016/j.radphyschem.2017.11.010

Fernandes, L., Ribeiro, H., Oliveira, A., Sanches Silva, A., Freitas, A., Henriques, M., \& Rodrigues, M. E. (2021). Portuguese honeys as antimicrobial agents against Candida species. Journal of Traditional and Complementary Medicine, 11(2), 130-136. https: //doi.org/10.1016/j.jtcme.2020.02.007

Finola, M. S., Lasagno, M. C., \& Marioli, J. M. (2007). Microbiological and chemical characterization of honeys from central Argentina. Food Chemistry, 100(4), 1649-1653. https://doi.org/10. 1016/j.foodchem.2005.12.046

Fit, N., Chirila, F., Nadas, G., Negrea, O., Bobis, O., \& Marghitas, L. (2014). Assessment of the antimicrobial effect of honey, treated by heat and ultraviolet radiation. Bulletin of University of Agricultural Sciences and Veterinary Medicine Cluj-Napoca. Veterinary Medicine, 71(2), 449-454. https://doi.org/10.15835/buasvmcn-vm: 10738

García, N. L. (2018). The current situation on the international honey market. Bee World, 95(3), 89-94. https://doi.org/10.1080/0005772X. 2018.1483814

Ghazali, H. M., Ming, T. C., \& Hashim, D. M. (1994). Effect of microwave heating on the storage and properties of starfruit honey. Asean Food Journal, 9(1), 1994.

Girma, A., Seo, W., \& She, R. C. (2019). Antibacterial activity of varying UMF-graded Manuka honeys. PLoS ONE, 14(10), 1-9. https: //doi.org/10.1371/journal.pone.0224495

Gonnet, M., Lavie, P., \& Louveaux, J. (1964). La pasteurisation des miels. Annales Abeilles, 7, 81-102.

Grainger, M. N. C., Manley-Harris, M., Fauzi, N. A. M., \& Farid, M. M. (2014). Effect of high pressure processing on the conversion of dihydroxyacetone to methylglyoxal in New Zealand mānuka (Leptospermum scoparium) honey and models thereof. Food Chemistry, 153, 134-139. https://doi.org/10.1016/j.foodchem.2013.12.017

Hebbar, H. U., Nandini, K. E., Lakshmi, M. C., \& Subramanian, R. (2003). Microwave and infrared heat processing of honey and its quality. Food Science and Technology Research, 9(1), 49-53. https: //doi.org/10.3136/fstr.9.49

Hillegas, S. L., \& Demirci, A. (2003). Inactivation of clostridium sporogenes in clover honey by pulsed UV-light treatment. Agricultural Engineering International. https://doi.org/10.13031/2013. 14232

Horniackova, M., Bucekova, M., Valachova, I., \& Majtan, J. (2017). Effect of gamma radiation on the antibacterial and antibiofilm activity of honeydew honey. European Food Research and Technology, 243(1), 81-88. https://doi.org/10.1007/s00217-016-2725-X

Hossain, K. S., Hossain, M. G., Moni, A., Rahman, M. M., Rahman, U. H., Alam, M., Kundu, S., Rahman, M. M., Hannan, M. A., \& Uddin, M. J. (2020). Prospects of honey in fighting against COVID19: Pharmacological insights and therapeutic promises. Heliyon, 6(12), e05798. https://doi.org/10.1016/j.heliyon.2020.e05798

Huhtanen, C. N. (1991). Gamma radiation resistance of Clostridium botulinum 62A and Bacillus subtilis spores in honey. Journal of Food Protection, 54(11), 894-896. https://doi.org/10.4315/ 0362-028X-54.11.894

Husøy, T., Haugen, M., Murkovic, M., Jöbstl, D., Stølen, L. H., Bjellaas, T., Rønningborg, C., \& Alexander, J. (2008). Dietary exposure to 5-hydroxymethylfurfural from Norwegian food and correlations with urine metabolites of short-term exposure. Food and Chemical
Toxicology, 46(12), 3697-3702. https://doi.org/10.1016/j.fct.2008.09. 048

Hussein, S. Z., Yusoff, K. M., Makpol, S., \& Yusof, Y. A. M. (2014). Does gamma irradiation affect physicochemical properties of honey? Clinical Therapeutics, 165(2), 125-133.

International Honey Commission. (2002). Harmonised methods of the international honey commission. Author.

Isaacs, N. S., \& Coulson, M. (1996). The effect of pressure on processes modelling the Maillard reaction. In R. Hayashi \& C. Balny (Eds.), Progress in biotechnology (Vol. 13, pp. 479-484). Elsevier.

Iurlina, M. O., \& Fritz, R. (2005). Characterization of microorganisms in Argentinean honeys from different sources. International Journal of Food Microbiology, 105(3), 297-304. https://doi.org/10.1016/ j.ijfoodmicro.2005.03.017

Jahan, N., Islam, M. A., Alam, F., Gan, S. H., \& Khalil, M. I. (2015). Prolonged heating of honey increases its antioxidant potential but decreases its antimicrobial activity. African Journal of Traditional, Complementary and Alternative Medicines, 12(4), 134-144. https:// doi.org/10.4314/ajtcam.v12i4.20

Jalali, S. F. S., Ehsani, A., Tajik, H., \& Ashtari, S. (2007). In vitro assessment of efficacy of gamma irradiation on the antimicrobial activity of Iranian honey. Journal of Animal and Veterinary Advances, 6(8), 996-999.

Jan, A., Sood, M., Sofi, S. A., \& Norzom, T. (2017). Non-thermal processing in food applications: A review. International Journal of Food Science and Nutrition, 2(6), 171-180.

Janghu, S., Bera, M. B., Nanda, V., \& Rawson, A. (2017). Studies on power ultrasound process optimization and its comparative analysis with conventional thermal processing for treatment of raw honey. Food Technology and Biotechnology, 55(4), 570-579. https://doi.org/10.17113/ftb.55.04.17.5263

Kabbani, D., Sepulcre, F., Gastón, E., \& Wedekind, J. (2011). Highpower ultrasound-assisted pasteurisation of honey. 11th International Congress on Engineering and Food.

Kabbani, D., Sepulcre, F., \& Wedekind, J. (2011). Ultrasound-assisted liquefaction of rosemary honey: Influence on rheology and crystal content. Journal of Food Engineering, 107(2), 173-178. https://doi. org/10.1016/j.jfoodeng.2011.06.027

Kamboj, R., Sandhu, S. R., Kaler, R. S., Bera, B. M., \& Nanda, V. (2019). Optimization of process parameters on hydroxymethylfurfural content, diastase and invertase activity of coriander honey. Journal of Food Science and Technology, 56(7), 3205-3214. https: //doi.org/10.1007/s13197-019-03774-X

Karabagias, V. K., Karabagias, I. K., \& Gatzias, I. (2018). The impact of different heating temperatures on physicochemical, color attributes, and antioxidant activity parameters of Greek honeys. Journal of Food Process Engineering, 41, 1-9. https://doi.org/10. 1111/jfpe.12668

Karabournioti, S., \& Zervalaki, P. (2001). The effect of heating on honey HMF and invertase. Apiacta, 4, 1-3.

Kato, Y., Kishi, Y., Okano, Y., Kawai, M., Shimizu, M., Suga, N., Yakemoto, C., Kato, M., Nagata, A., \& Miyoshi, N. (2021). Methylglyoxal binds to amines in honey matrix and 2 -methoxyacetophenone is released in gaseous form into the headspace on the heating of manuka honey. Food Chemistry, 337, 127789. https://doi.org/10. 1016/j.foodchem.2020.127789

Kedzierska-Matysek, M., Florek, M., Wolanciuk, A., Skalecki, P., \& Litwinczuk, A. (2016). Characterisation of viscosity, colour, 5hydroxymethylfurfural content and diastase activity in raw rape 
honey (Brassica napus) at different temperatures. Journal of Food Science and Technology, 53(4), 2092-2098. https://doi.org/10.1007/ s13197-016-2194-Z

Kędzierska-Matysek, M., Stryjecka, M., Teter, A., Skałecki, P., Domaradzki, P., \& Florek, M. (2021). Relationships between the content of phenolic compounds and the antioxidant activity of polish honey varieties as a tool for botanical discrimination. Molecules, 26(6), 1810. https://doi.org/10.3390/molecules26061810

Khalil, M. I., Islam, M. A., Alam, N., Gan, S. H., \& Sulaiman, S. A. (2015). Irradiation and evaporation enhance physicochemical characteristics, AEAC, FRAP, protein and proline contents of tualang honey. Journal of Food Biochemistry, 39(6), 742-753. https://doi.org/10.1111/jfbc.12182

Kowalski, S. (2013). Changes of antioxidant activity and formation of 5-hydroxymethylfurfural in honey during thermal and microwave processing. Food Chemistry, 141, 1378-1382. https://doi. org/10.1016/j.foodchem.2013.04.025

Kowalski, S., \& Lukasiewicz, M. (2017). Diastase and invertase activity changes and 5-hydroxymethyl-2-furfural formation in honeys under influence of microwave irradiation: HMF, enzymes activity under influence of microwave. Journal of Food Process Engineering, 40(2), e12410. https://doi.org/10.1111/jfpe.12410

Kowalski, S., Lukasiewicz, M., Bednarz, S., \& Panus, M. (2012). Diastase number changes during thermal and microwave processing of honey. Czech Journal Food Science, 30(1), 21-26. https://doi.org/10. 17221/123/2010-CJFS

Kretavičius, J., Kurtinaitienè, B., Račys, J., \& Ceksteryte, V. (2010). Inactivation of glucose oxidase during heat-treatment decrystallization of honey. Zemdirbyste Agriculture, 97(4), 115-122.

Lee, C.-H., Chen, K.-T., Lin, J.-A., Chen, Y.-T., Chen, Y.-A., Wu, J.-T., \& Hsieh, C.-W. (2019). Recent advances in processing technology to reduce 5-hydroxymethylfurfural in foods. Trends in Food Science \& Technology, 93, 271-280. https://doi.org/10.1016/j.tifs.2019.09.021

Leon-Ruiz, V., Vera, S., Gonzalez-Porto, A., \& Paz San Andres, M. (2011). Vitamin C and sugar levels as simple markers for discriminating Spanish honey sources. Journal of Food Science, 76(3), 356361. https://doi.org/10.1111/j.1750-3841.2011.02041.x

Leyva-Daniel, D. E., Escobedo-Avellaneda, Z., Villalobos-Castillejos, F., Alamilla-Beltrán, L., \& Welti-Chanes, J. (2017). Effect of high hydrostatic pressure applied to a Mexican honey to increase its microbiological and functional quality. Food and Bioproducts Processing, 102, 299-306. https://doi.org/10.1016/j.fbp.2017.01.001

Lucey, J. (2015). Raw milk consumption risks and benefits. Nutrition Today, 50(4), 189-193. https://doi.org/10.1097/NT. 0000000000000108

Ma, Y., Zhang, B., Li, H., Li, Y., Hu, J., Li, J., Wang, H., \& Deng, Z. (2017). Chemical and molecular dynamics analysis of crystallization properties of honey. International Journal of Food Properties, 20(4), 725-733. https://doi.org/10.1080/10942912.2016.1178282

Mahnot, N. K., Saikia, S., \& Mahanta, C. L. (2019). Quality characterization and effect of sonication time on bioactive properties of honey from North East India. Journal of Food Science and Technology, 56(2), 724-736. https://doi.org/10.1007/s13197-018-3531-1

Majkut, M., Kwiecińska-Piróg, J., Wszelaczyńska, E., Pobereżny, J., Gospodarek-Komkowska, E., Wojtacki, K., \& Barczak, T. (2021). Antimicrobial activity of heat-treated Polish honeys. Food Chemistry, 343, 128561. https://doi.org/10.1016/j.foodchem.2020.128561

Manyi-loh, C. E., Clarke, A. M., Munzhelele, T., Green, E., Mkwetshana, N. F., \& Ndip, R. N. (2010). Selected South African honeys and their extracts possess in vitro anti-helicobacter pylori activity. Archives of Medical Research, 41(5), 324-331. https://doi.org/10. 1016/j.arcmed.2010.08.002

Marghtas, L. A., Bonta, V., \& Dezmirean, D. S. (2011). Influence of UV radiation upon pesticide residues from contaminated honey. Bulletin of University of Agricultural Sciences and Veterinary Medicine Cluj-Napoca. Animal Science and Biotechnologies, 68(1-2). https://doi.org/10.15835/buasvmcn-asb:68:1-2:6656

Matsuda, A., \& Sabato, S. (2004). Effect of irradiation on Brazilian honeys' consistency and their acceptability. Radiation Physics and Chemistry, 71(1-2), 109-112. https://doi.org/10.1016/j.radphyschem.2004.03.068

McLoone, P., Tabys, D., \& Fyfe, L. (2020). Honey combination therapies for skin and wound infections: A systematic review of the literature. Clinical, Cosmetic and Investigational Dermatology, 13, 875-888. https://doi.org/10.2147/CCID.S282143

McLoone, P., Warnock, M., \& Fyfe, L. (2016). Honey: A realistic antimicrobial for disorders of the skin. Journal of Microbiology, Immunology and Infection, 49, 161-167. https://doi.org/10.1016/j. jmii.2015.01.009

Migdal, W., Owczarczyk, H., Kedzia, B., Kedzia-Holderna, E., \& Madajczyk, D. (2000). Microbiological decontamination of natural honey by irradiation. Radiation Physics and Chemistry, 57, 285288.

Molan, P. C., \& Allen, K. L. (1996). The effect of gamma-irradiation on the antibacterial activity of honey. Journal of Pharmacy and Pharmacology, 48(11), 1206-1209. https://doi.org/10.1111/j.2042-7158. 1996.tb03922.x

Moline, M., Fernandez, N., Medici, S., Fasce, D., \& Gende, L. (2015). Effect of microwave treatment on microbial contamination of honeys and in their physicochemical and thermal properties. Polish Journal of Food and Nutrition Sciences, 65(2), 119-126. https://doi. org/10.1515/pjfns-2015-0031

Nanda, V., Bera, M. B., \& Bakhshi, A. K. (2006). Optimization of the process parameters to establish the quality attributes of hydroxymethylfurfural content and diastatic activity of sunflower (Helianthus annus) honey using response surface methodology. European Food Research and Technology, 222(1-2), 64-70. https: //doi.org/10.1007/s00217-005-0133-8

Nayik, G. A., \& Nanda, V. (2015). Effect of thermal treatment and $\mathrm{pH}$ on antioxidant activity of saffron honey using response surface methodology. Journal of Food Measurement and Characterization, 10, 64-70. https://doi.org/10.1007/s11694-015-9277-9

Nayik, G., \& Nanda, V. (2016). Application of response surface methodology to study the combined effect of temperature, time and $\mathrm{pH}$ on antioxidant activity of cherry (Prunus avium) honey. Polish Journal of Food and Nutrition Sciences, 66(4), 287-293. https://doi.org/10.1515/pjfns-2015-0055

Nolan, V. C., Harrison, J., \& Cox, J. A. G. (2019). Dissecting the antimicrobial composition of honey. Antibiotics, 8(1), 251.

Olas, B. (2020). Honey and its phenolic compounds as an effective natural medicine for cardiovascular diseases in humans? Nutrients, 12(2), 1-14. https://doi.org/10.3390/nu12020283

Oliveira, A., Ribeiro, H. G., Silva, A. C., Silva, M. D., Sousa, J. C., Rodrigues, C. F., Melo, L. D. R., Henriques, A. F., \& Sillankorva, S. (2017). Synergistic antimicrobial interaction between honey and phage against Escherichia coli biofilms. Frontiers in Microbiology, 8, 2407. https://doi.org/10.3389/fmicb.2017. 02407 
Önür, İ., Misra, N. N., Barba, F. J., Putnik, P., Lorenzo, J. M., Gökmen, V., \& Alpas, H. (2018). Effects of ultrasound and high pressure on physicochemical properties and HMF formation in Turkish honey types. Journal of Food Engineering, 219, 129-136. https://doi.org/10. 1016/j.jfoodeng.2017.09.019

Organic Federation of Canada. (2020). Organic production systems: General principles and management standards. Section 7.1 - Apiculture. Canadian General Standards Board: Standards Council of Canada. http://www.organicfederation.ca/ publication-2020-canadian-organic-standards

Ota, M., Ishiuchi, K., Xu, X., Minami, M., Nagachi, Y., Yagi-Utsumi, M., Tabuchie, Y., Cai, S.-Q., \& Makino, T. (2019). The immunostimulatory effects and chemical characteristics of heated honey. Journal of Ethnopharmacology, 228, 11-17. https://doi.org/10.1016/ j.jep.2018.09.019

Özkök, D., \& Silici, S. (2016). Effects of honey HMF on enzyme activities and serum biochemical parameters of Wistar rats. Environmental Science and Pollution Research, 23, 20186-20193. https:// doi.org/10.1007/s11356-016-7218-8

Pimentel-Gonzalez, D. J., Basilio-Cortes, U. A., Hernandez-Fuentes, A. D., Figueira, A. C., Quintero-Lira, A., \& Campos-Montiel, R. G. (2017). Effect of thermal processing on antibacterial activity of multifloral honeys. Journal of Food Process Engineering, 40, e12279. https://doi.org/10.1111/jfpe.12279

Pimentel-González, D. J., Jiménez-Alvarado, R., Hernández-Fuentes, A. D., Figueira, A. C., Suarez-Vargas, A., \& Campos-Montiel, R. G. (2016). Potentiation of bioactive compounds and antioxidant activity in artisanal honeys using specific heat treatments. Journal of Food Biochemistry, 40(1), 47-52. https://doi.org/10.1111/jfbc.12186

Pinto, C. A., Moreira, S. A., Fidalgo, L. G., Inácio, R. S., Barba, F. J., \& Saraiva, J. A. (2020). Effects of high-pressure processing on fungi spores: Factors affecting spore germination and inactivation and impact on ultrastructure. Comprehensive Reviews in Food Science and Food Safety, 19(2), 553-573. https://doi.org/10.1111/1541-4337. 12534

Postmes, T., van den Bogaard, A. E., \& Hazen, M. (1995). The sterilization of honey with cobalt 60 gamma radiation: A study of honey spiked with spores of Clostridium botulinum and Bacillus subtilis. Experientia, 51(9-10), 986-989. https://doi.org/10.1007/BF01921753

Pyrzynska, K., \& Biesaga, M. (2009). Analysis of phenolic acids and flavonoids in honey. Trends in Analytical Chemistry, 28(7), 893902. https://doi.org/10.1016/j.trac.2009.03.015

Quintero-Lira, A., Ángeles Santos, A., Aguirre-Álvarez, G., Reyes-Munguía, A., Almaraz-Buendía, I., \& CamposMontiel, R. G. (2017). Effects of liquefying crystallized honey by ultrasound on crystal size, 5-hydroxymethylfurfural, colour, phenolic compounds and antioxidant activity. European Food Research and Technology, 243(4), 619-626. https://doi.org/10.1007/s00217-016-2775-0

Rajapakse, T. B. J. (2011). High-power ultrasound to control honey crystallisation (Short report No. 144). University of Queensland.

Razali, M. F., Mohd Fauzi, N. A., Sulaiman, A., Talip, B. A., \& Rahman, A. A. (2019). Effect of high-pressure processing on prebiotic potential of stingless bee (Kelulut) honey: Tested upon Lactobacillus acidophilus and Lactobacillus brevis. Journal of Food Processing and Preservation, 43(7), e13946. https://doi.org/10.1111/jfpp.13946

Reynolds, A. (2019). Influence of microwave treatment on honey quality. Progressive Agriculture, 30(1), 125-140. https://doi.org/10. 3329/pa.v30i1.42219
Roberts, A. E. L., Powell, L. C., Pritchard, M. F., Thomas, D. W., Jenkins, R. E., \& Carter, D. (2019). Anti-pseudomonad activity of manuka honey and antibiotics in a specialized ex vivo model simulating cystic fibrosis lung infection. Frontiers in Microbiology, 10, 1-10. https://doi.org/10.3389/fmicb.2019.00869

Roig-Sagués, A. X., Gervilla, R., Pixner, S., Terán-Peñafiel, T., \& Hernández-Herrero, M. M. (2018). Bactericidal effect of ultraviolet-C treatments applied to honey. LWT - Food Science and Technology, 89, 566-571. https://doi.org/10.1016/j.lwt.2017.11.010

Sahinler, N. (2007). Effects of heating and storage on hydroxy methylfurfural and diastase activity of different Turkish honeys. Journal of Apicultural Research, 46(1), 34-39. https://doi.org/10.1080/ 00218839.2007.11101364

Saric, G., Markovic, K., Vukicevic, D., Lez, E., Hruskar, M., \& Vahcic, N. (2013). Changes of antioxidant activity in honey after heat treatment. Czech Journal of Food Science, 31(6), 601-606.

Saxena, S., Gautam, S., \& Sharma, A. (2010). Microbial decontamination of honey of Indian origin using gamma radiation and its biochemical and organoleptic properties. Journal of Food Science, 75(1), M19-M27. https://doi.org/10.1111/j.1750-3841.2009.01405.X

Saxena, S., Panicker, L., \& Gautam, S. (2014). Rheology of Indian honey: Effect of temperature and gamma radiation. International Journal of Food Science, 2014, 1-6. https://doi.org/10.1155/2014/ 935129

Scepankova, H., Saraiva, J. A., \& Estevinho, L. M. (2017). Honey health benefits and uses in medicine. In J. Alvarez-Suarez (Ed.), Bee products - Chemical and biological properties (pp. 8396). Springer International Publishing. https://doi.org/10.1007/ 978-3-319-59689-1_4

Schvezov, N., Pucciarelli, A. B., Valdes, B., \& Dallagnol, A. M. (2020). Characterization of yateí (Tetragonisca fiebrigi) honey and preservation treatments: Dehumidification, pasteurization and refrigeration. Food Control, 111, 107080. https://doi.org/10.1016/j.foodcont. 2019.107080

Semprini, A., Singer, J., Braithwaite, I., Shortt, N., Thayabaran, D., Mcconnell, M., Weatherall, M., \& Beasley, R. (2019). Kanuka honey versus aciclovir for the topical treatment of herpes simplex labialis: A randomised controlled trial. BMJ Open, 9, e026201. https://doi.org/10.1136/bmjopen-2018-026201

Serreira, M. J., de Alencar Arnaut de Toledo, V., \& Marchini, L. C. (2010). Microorganisms in organic and non organic honey samples of africanized honeybees. Journal of Apicultural Science, 54(1), 149-154. https://doi.org/10.1186/1472-5

Shapla, U. M., Alam, N., Khalil, I., \& Gan, S. H. (2018). 5-Hydroxymethylfurfural (HMF) levels in honey and other food products: Effects on bees and human health. Chemistry Central Journal, 12, 35. https://doi.org/10.1186/s13065-018-0408-3

Singh, I., \& Singh, S. (2018). Honey moisture reduction and its quality. Journal of Food Science and Technology, 55(10), 3861-3871. https://doi.org/10.1007/s13197-018-3341-5

Snowdon, J. A., \& Cliver, D. O. (1996). Microorganisms in honey. International Journal of Food Microbiology, 31(1-3), 1-26. https: //doi.org/10.1007/978-4-431-53898-1

Stasiak, D. M., \& Dolatowski, Z. J. (2007). Effect of sonication on the crystallization of honeys. Polish Journal of Food and Nutrition Sciences, 57(3), 133-136.

Subramanian, R., Umesh Hebbar, H., \& Rastogi, N. K. (2007). Processing of honey: A review. International Journal of Food Properties, 10(1), 127-143. https://doi.org/10.1080/10942910600981708 
Thrasyvoulou, A., Manikis, J., \& Tselios, D. (1994). Liquefying crystallized honey with ultrasonic waves. Apidologie, 25(3), 297-302. https://doi.org/10.1051/apido:19940304

Thrasyvoulou, A., Tananaki, C., Goras, G., Dimou, M., Liolios, V., Kanelis, D., \& Goras, G. (2018). Legislation of honey criteria and standards. Journal of Apicultural Research, 57(1), 88-96. https:// doi.org/10.1080/00218839.2017.1411181

Tosi, E. A., Ré, E., Lucero, H., \& Bulacio, L. (2004). Effect of honey high-temperature short-time heating on parameters related to quality, crystallisation phenomena and fungal inhibition. $L W T$ Food Science and Technology, 37(6), 669-678. https://doi.org/10. 1016/j.lwt.2004.02.005

Turhan, I., Tetik, N., Karhan, M., Gurel, F., \& Reyhan Tavukcuoglu, H. (2008). Quality of honeys influenced by thermal treatment. LWT - Food Science and Technology, 41(8), 1396-1399. https://doi. org/10.1016/j.lwt.2007.09.008

Verzola, F. F. V., Marquez, D. C., Punzalan, J. M., Quiming, N. S., Nicolas, M. G., \& Simon, R. C. (2019). Effect of gamma-irradiation on the antioxidant activity of Lukotan honey from Sierra Madre. Proceedings of the Samahang Pisika Ng Pilipinas, SPP-2019-PA09.

Watanabe, K., Rahmasari, R., Matsunaga, A., Haruyama, T., \& Kobayashi, N. (2014). Anti-influenza viral effects of honey in vitro: Potent high activity of manuka honey. Archives of Medical Research, 45(5), 359-365. https://doi.org/10.1016/j.arcmed.2014.05. 006

World Health Organization. (2014). Antimicrobial resistance: Global report on surveillance. Author. https://www.who.int/ drugresistance/documents/surveillancereport/en/
World Health Organization. (2018). Botulism. https://www.who.int/ news-room/fact-sheets/detail/botulism

Yao, Y., Pan, Y., \& Liu, S. (2020). Power ultrasound and its applications: A state-of-the-art review. Ultrasonics Sonochemistry, 62, 104722. https://doi.org/10.1016/j.ultsonch.2019.104722

Yu, H., Liu, Y., Li, L., Guo, Y., Xie, Y., Cheng, Y., \& Yao, W. (2020). Ultrasound-involved emerging strategies for controlling foodborne microbial biofilms. Trends in Food Science \& Technology, 96, 91-101. https://doi.org/10.1016/j.tifs.2019.12.010

Zamora, M. C., \& Chirife, J. (2006). Determination of water activity change due to crystallization in honeys from Argentina. Food Control, 17(1), 59-64. https://doi.org/10.1016/j.foodcont.2004. 09.003

Zarei, M., Fazlara, A., \& Tulabifard, N. (2019). Effect of thermal treatment on physicochemical and antioxidant properties of honey. Heliyon, 5, e01894. https://doi.org/10.1016/j.heliyon.2019. e01894

How to cite this article: Scepankova, H., Pinto, C. A., Paula, V., Estevinho, L. M., \& Saraiva, J. A. (2021). Conventional and emergent technologies for honey processing: A perspective on microbiological safety, bioactivity, and quality. Compr Rev Food Sci Food Saf, 1-29.

https://doi.org/10.1111/1541-4337.12848 